\section{Determining the level of usability the techniques of the Western music violin performer for the field of Turkish music violin teaching}

Batı müziği keman icracılığ1 tekniklerinin Türk müziği keman öğretimi alanında kullanılabilirlik düzeylerinin belirlenmesi $^{1}$

\author{
Ali Korkut Uludağ \\ Ferhat Devecioğlu ${ }^{3}$
}

\begin{abstract}
This work has been made in order to see how much the techniques are useful at West music playing violin on teaching Turkish music playing violin. Studying group was formed by the graduate students $(\mathrm{n}=8)$ who attends Kafkas University State Conservatory Traditional Turkish Music during Autumn- sprig term.

Experimental value which contains pre test and final test groups is used in the investigation. The investigation consists of control groups $(n=4)$ and experience groups $(n=4)$. During the experimental process which lasted 8 weeks, Although experience group students were applied a teaching programme which was prepared by the researcher, control group students were applied traditional teaching methods. At the first stage of experimental process equivalance test and then pre test - post test was applied to them. In order to designate musical and technical skills of working group students, performance evaluation scale was used with expert opinions. There was a kind of song during the equivalance test. There were peşrev,
\end{abstract}

Özet

$\mathrm{Bu}$ çalışma, Batı müziği keman çalım tekniklerinin Türk müziği keman öğretimi alanında kullanılmasının öğrenciler üzerinde ne derece etkili olduğunu belirlemek amaciyla gerçekleştirilmiştir. Araştırmanın çalışma grubu, 2015 - 2016 eğitim - öğretim yllı güz - bahar yarryllinda Kafkas Üniversitesi Devlet Konservatuvar1 Geleneksel Türk Müziği Bölümünde öğrenim gören lisans öğrencileri $(n=8)$ tarafindan oluşturulmuştur.

Araştırmada ön test ve son test kontrol gruplu deneysel desen kullanılmıştır. Çalışma grubu öğrencileri yansız atama yoluyla kontrol grubu $(n=4)$ ve deney grubu $(n=4)$ olarak belirlenmiştir. Sekiz haftalık süreci kapsayan deneysel işlem süreci içerisinde deney grubu öğrencilerine araştırmacı tarafindan hazırlanan bir öğretim yaklaşımı uygulanırken kontrol grubu ile dersler geleneksel yöntemlerle sürdürülmüştür. Deneysel işlem süreci öncesinde ilk olarak denklik testi ve devamında ise ön test - son test uygulamalar1 gerçekleştirilmiştir. Çalışma grubu öğrencilerinin

\footnotetext{
${ }^{1} \mathrm{Bu}$ araştırma, Ali Korkut Uludağ’’n danışmanlığında Ferhat Devecioğlu tarafindan hazırlanan ve 10.01.2017 tarihinde savunması gerçekleştirilen yüksek lisans tezinden üretilmiştir.

2 Doç. Dr., Atatürk Üniversitesi, Kazım Karabekir Eğitim Fakültesi, Güzel Sanatlar Eğitimi Bölümü, Müzik Eğitimi Ana Bilim Dalı, korkutuludag@atauni.edu.tr
}

3 M.A., M.E.B., ferhatdev63@msn.com 
Uludağ, A. K., \& Devecioğlu, F. (2020). Batı müziği keman icracıllğı tekniklerinin Türk müziği keman öğretimi alanında kullanılabilirlik düzeylerinin belirlenmesi. Journal of Human Sciences, 17(2), 432-457. doi:10.14687/jhs.v17i2.5788

saz semâi and a kind of song during the pre test and post test precess. Student`s instrument performance was recorded by a camera and then marked by experts.

In order to analyze the datas, Mann - Whitney $\mathrm{U}$ Test was used to see whether there was a huge difference between pre test and final test between control and experiment groups. Datas were analyzed by using "SPSS 20" pocket programme.

Considering the outcomes as a whole, we can conclude that the teaching programme which was prepared by the researcher is effective and good outcomes arised.

Keywords: Education; music education; Turkish music; violin; violin education.

(Extended English abstract is at the end of this document) müzikal ve teknik becerilerinin belirlenmesi amaciyla uzman görüşleri doğrultusunda hazırlanan performans değerlendirme ölçeği kullanılmıstır. Araştırmanın denklik testinde 1 adet şark1 türü, ön test ve son test aşamalarında ise peşrev, saz semâi ile şarkı türlerinden birer esere yer verilmiştir. Öğrencilerin çalg1 performansları kamera ile kayda alınmış ve uzmanlar tarafindan puanlandirilmasi sağlanmıştır.

Elde edilen verilerin analizi için, kontrol ve deney grubu öğrencilerinin ön test ve son test sonuçları arasında anlamlı bir fark olup olmadığını belirlemek amacıyla Mann - Whitney U Testi kullanılmıştır. Toplanan veriler, "SPSS 20" paket programları kullanılarak analiz edilmiştir.

Elde edilen sonuçlar bir bütün olarak ele alındığında araştırmacı tarafindan hazırlanan deneysel işlem süreci üzerinden olumlu sonuçlara ulaşıldığı görülmektedir.

Anahtar Kelimeler: Eğitim; müzik eğitimi; Türk müziği; keman çalg1sı; keman çalg1 eğitimi.

\section{GİRİŞ}

Ses olanakları son derece zengin bir çalg1 olan keman, dünyanın birçok ülkesinde kullanılan en yaygın, en sevilen çalgılardan biridir (Say, 2005, s. 290). Keman, Ortaçağ dan günümüze gerek yapımı gerekse icrası ve eğitimi ile müzik insanları tarafindan merak edilen, hakkında birçok araştırma yapılan bir çalgı olmuştur. Bütün dünyada olduğu gibi Türkiye'de de hem geleneksel hem de batı müziği tarzında icracıları yetişmiş, besteler yapılmış, metotlar yazılmıştır (Kurtaslan, 2009, s. 411). Hatipoğlu'na (2017) göre Avrupa temelli bir saz olan keman, Osmanlı topraklarında icra edilmeye başlandığ1 18. yüzyıl itibari ile Türk müziğinin temel yaylı sazları olan rebab, kemençe ve sinekemanın yerini alarak büyük bir önem kazanmıştır.

Türk müziği, kendine özgü ses sistemi, usûl anlayışı, çalgıları, türleri ve biçimleriyle geçmişten günümüze kendi kültürünü yansitan ulusal bir müzik türüdür. Türk müziğini Bat1 müziğinden ayıran en büyük özelliği ise ses sistemidir. Batı müziğinde, tam bir ses aralığının (büyük ikili) eşit bir biçimde ikiye bölünerek ve bir oktav (sekizli) aralığında da toplam 12 adet yarım ses aralıklardan oluşan ses sistemi kullanılmaktadır. Bu ses sistemine tampere ses sistemi denilmektedir. Türk müziğinde ise koma sistemi kullanılmaktadır. Tamay ve Matyakubov (2019) bu noktada tanini aralığın dokuz eşit parçaya, bakiye aralı̆̆ ise dört eşit parçaya ayrıldığına ve her parçanın "koma" olarak adlandırıldığına dikkat çekmektedir. Koma aralığı, 24 lü ses sistemine göre Türk müziğinde kullanılan en küçük aralıktır.

Türk müziğinin ses, usûl çalg1, tür ve biçim dışında diğer önemli bir özelliği de akort sistemidir. Özkan'a (1998) göre Türk mûsskîsinde esas akort bolâhenk denilen akorttur ve bu akort sisteminde diyapazonun çıkarttığ1 la sesi, re (nevâ) 440 hertz olarak kabul edilerek akort buna göre yapılmaktadır. Türk müziğinde bolâhenk akort sistemini kullandığından Türk müziği çalgıları bu sistemde icra edilmektedir. Bu çalgılara klasik kemençe, ney ve tanbur vb. örnek olarak gösterilebilir.

Türk müziğine yönelik yapılan pedagojik materyal ve akademik içerikli çalışmalarda dikkat edilmesi gereken önemli noktalar bulunmaktadır. Demirci (2013) Türk müzik kültürünü, gelecek 
Uludağ, A. K., \& Devecioğlu, F. (2020). Batı müziği keman icracıllğı tekniklerinin Türk müziği keman öğretimi alanında kullanılabilirlik düzeylerinin belirlenmesi. Journal of Human Sciences, 17(2), 432-457. doi:10.14687/jhs.v17i2.5788

nesillere daha çağdaş ve modern bir yapıyla taşıyabilmek için, onu iyi tanımak ve aktarımda doğru yöntemler kullanarak ifade etmek gerektiği yönünde görüş belirtmektedir. Bununla birlikte, Türk müziğinin zenginliklerini hem icra yorumlama, hem de akademik anlamda çalışmalar yaparak ulusal ve uluslararası ortamlarda paylaşmanın yerinde olacağı görüşündedir.

Keman çalgıs1, Türk ve Batı müziğinde yaygın olarak kullanılmaktadır. Kemana ait Türk ve Batı müziğindeki tellerin akort frekansları eşit durumdadır. Türk müziği ses sistemi gereği tellerin nota adları değişiklik göstermektedir. Bu durum Tablo 1. 1.'de sunulmuştur.

Tablo 1.1. Keman Çalgısı Tellerinin Frekanslar (Devecioğlu, 2017, s. 68).

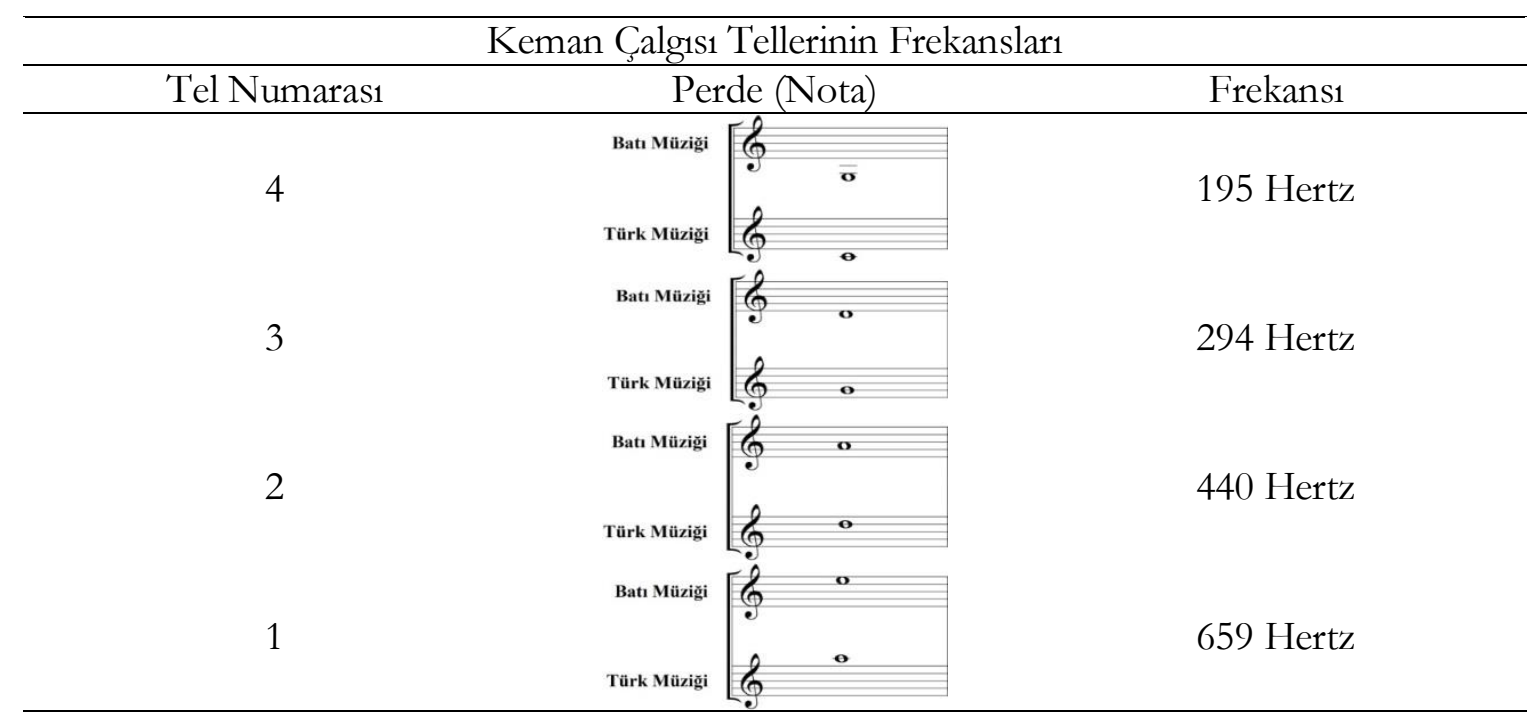

Bat1 müziği eserlerinin önemli müzisyenler tarafindan bestelendiği ve sistematik bir yapıya dönüştürüldüğü bilinmektedir. Çalg1 eğitiminde doğal bir süreç olarak eserlerin seslendirilmesinde teknik açıdan belirli problemler ortaya çıkmıştır. Görülen sorunlara yönelik çözüm üretebilmek amacıyla, etütler, alıştırmalar ve çeşitli icra teknikleri geliştirilmiştir. Türk müziği alanında ise bu tarz sistemli ve programlı çalışmalara yönelik yoğun bir ihtiyaç duyulmaktadır. Alkaç ve Kaya (2017) işte bu noktada, Türk müziği çalg1 eğitimi için kaynak oluşturabilecek yeterli sayıda metot ve eser repertuvarının olmadığına dikkat çekmektedirler.

Çalg1 eğitiminde săg ve sol el için geliştirilen teknik çalışmalar, genellikle seslendirmede karşılaşılan birtakım zorlukları aşabilmek amacıyla hazırlanmışıı. Bu teknikler doğrultusunda yapılan çalışmalar ile ulaşılması istenen duygular daha iyi ifade edilebilir. Toplu olarak gerçekleştirilen Türk müziği keman icracllı̆̆nda sağ ve sol el tekniklerinin bir disiplin içinde olmayışı, işitsel olarak birtakım sorunların ortaya çıkmasına sebep olmaktadır. Bu durum, sadece işitsel olarak ele alınmamalıdır. Tamay (2015) pozisyonlu çalış tekniğini tartışmasız, ihtiyaçtan doğmuş bir öğrenme ve öğretme tekniği olarak tanımlamakta ve bu tekniği aynı zamanda ortak bir dil oluşturma çabası olarak ifade etmektedir.

$\mathrm{Bu}$ çalışma, keman çalgısında yer alan sağ ve sol el tekniklerinin Türk müziği eserleri üzerinde adapte edilmesi amacıyla hazırlanmıştır. Araştırmanın deneysel işlem sürecini kapsayan eserlerin orijinal yapısını bozacak hiçbir yaklaşımda bulunulmamıştır. Çalışmayı oluşturan tüm unsurlar öncelikli olarak Türk müziği keman çalgısı öğretimi alanına dönük olarak tasarlanmıştır.

\subsection{Problem Cümlesi}

Keman eğitiminde Batı müziği keman öğretimi teknikleri ile hazırlanan öğretim yaklaşımlarının Türk müziği eserleri üzerinde kullanılabilirlik düzeyi nasıldır?

\subsection{Alt Problemler}

1. Öğrencilerin, peşrev türündeki eserin notasını doğru çalabilme becerileri ne düzeyde gelişmiştir? 
Uludağ, A. K., \& Devecioğlu, F. (2020). Batı müziği keman icracıllğı tekniklerinin Türk müziği keman öğretimi alanında kullanılabilirlik düzeylerinin belirlenmesi. Journal of Human Sciences, 17(2), 432-457. doi:10.14687/jhs.v17i2.5788

2. Öğrencilerin, peşrev türündeki eseri doğru ritim ile çalabilme becerileri ne düzeyde gelişmiştir?

3. Öğrencilerin, peşrev türündeki eserde sağ eldeki teknik davranışları ile çalabilme becerileri ne düzeyde gelişmiştir?

4. Öğrencilerin, peşrev türündeki eserde sol eldeki teknik davranışları ile çalabilme becerileri ne düzeyde gelişmiştir?

5. Öğrencilerin, peşrev türündeki eseri doğru tempo ile çalabilme becerileri ne düzeyde gelişmiştir?

6. Öğrencilerin, peşrev türündeki eseri müzikal ifadeyle kabul edilebilir bir tempo ile çalabilme becerileri ne düzeyde gelişmiştir?

\section{ARAŞTIRMA MODELI}

Araştırmanın modelini ön test - son test kontrol gruplu model oluşturmuştur. Deneysel çalışmalarda görülen temel sorunlardan birisi deneklerin seçimi ve bu durum ön test - son test kontrol gruplu desenlerde çok daha önemlidir. Büyüköztürk'e (2014) göre bu durumun sebebi bağımlı değisskene ait deney ve kontrol grupların puanlarının deney sonrasındaki farklılıkları, deney öncesi farklılıklardan kaynaklanıyor olmasından kaynaklanmaktadır. Bununla birlikte ön test - son test kontrol gruplu desenin, deneysel işlemin bağımlı değişken üzerindeki etkisinin test edilmesiyle ilgili olarak araştırmacıya yüksek bir istatistiksel güç sağlayan, elde edilen bulguların neden - sonuç bağlamında yorumlanmasina olanak veren ve davranış bilimlerinde sıklıkla kullanılan güçlü bir desen olduğu söylenebilir (Büyüköztürk, 2014, s. 24).

\section{1 Çalışma Grubu}

Bu araştırmanın çalışma grubunu, 2015 - 2016 yılı güz ve bahar yarıyllı içinde Kafkas Üniversitesi Devlet Konservatuvarı Geleneksel Türk Müziği Bölümünde keman çalgısı alanında eğitim gören $(n=8)$ öğrenciler oluşturmuştur. Öğrenciler, araştırmaya gönüllülük esasına dayalı olarak katılmıştır. Katılımcılar için; çalışmanın içeriği, süreci ve kazanımları hakkında bilgiler sunmak amacıyla "Gönüllü Katılım Formu" hazırlanmıştır.

\subsection{Veri Toplama Araçları}

Deneysel işlem süreci öncesi kontrol ve deney gruplarının oluşturulması için öğrencilere bir denklik testi uygulanmıştır. Devamında ise öntest ve sontest aşamalarında kullanılmak üzere Performans Değerlendirme Ölçeği kullanılmıştır. Bu ölçeğin güvenirliğini belirlemek için puanlayıc1 güvenirliğine bağlı korelasyon katsayısı 0,92 olarak hesaplanmıştır. Bu sonuca göre performans değerlendirme ölçeğinden elde edilen sonuçların güvenilir olduğu sonucuna ulaşılmıştır.

\subsubsection{Denklik Testi}

Deneysel çalışmalarda önemli bir sorun deneklerin seçimidir. Bu sorun ön test - son test kontrol gruplu desenlerde çok daha önemlidir. Çünkü bağımlı değişkene ait deney ve kontrol grupların puanlarının deney sonrasindaki farklilıkları, deney öncesi farklılıklardan kaynaklanıyor olabilir (Büyüköztürk, 2014, s. 22). Bu testte çalışma grubu öğrencileri TRT Türk Sanat Müziği sözlü eserler arşivinin 1767 sayılı repertuvar olan "Bir Akşam Son Defa Seni Görmeden” adlı eseri seslendirmişlerdir. $\mathrm{Bu}$ eser, Şekil 2. 1`de sunulmuştur. Bu eser çalışma grubu öğrencilerine araştırmanın ön test aşamasından 3 gün önce verilmiştir. Bu üç günlük çalışma sonucundaki öğrenci performanslar1 Kafkas Üniversitesi Devlet Konservatuvar1 dersliklerinde video kayıt altına alınmıştır. Elde edilen görüntü kayıtları, 3 uzman tarafindan değerlendirilmiş ve ortalamaları alınmıştır. Bu test sonucunda kontrol ve deney grupları arasında puan eşitlikleri sağlanmış ve yansız atama yoluyla da her iki grubun atamaları gerçekleştirilmiştir. Büyüköztürk'e (2014) göre iki gruptaki deneklerin başlangıçtaki farklılıkların en aza indirgemenin yolu deneklerin uygun yöntemlerle grupların atanmasından geçer. Deneklerin iki gruba ayrılmasında izlenen iki temel yöntemden biri eşleştirme, diğeri yansız atamadır. 
Uludağ, A. K., \& Devecioğlu, F. (2020). Batı müziği keman icracıllğı tekniklerinin Türk müziği keman öğretimi alanında kullanılabilirlik düzeylerinin belirlenmesi. Journal of Human Sciences, 17(2), 432-457. doi:10.14687/jhs.v17i2.5788

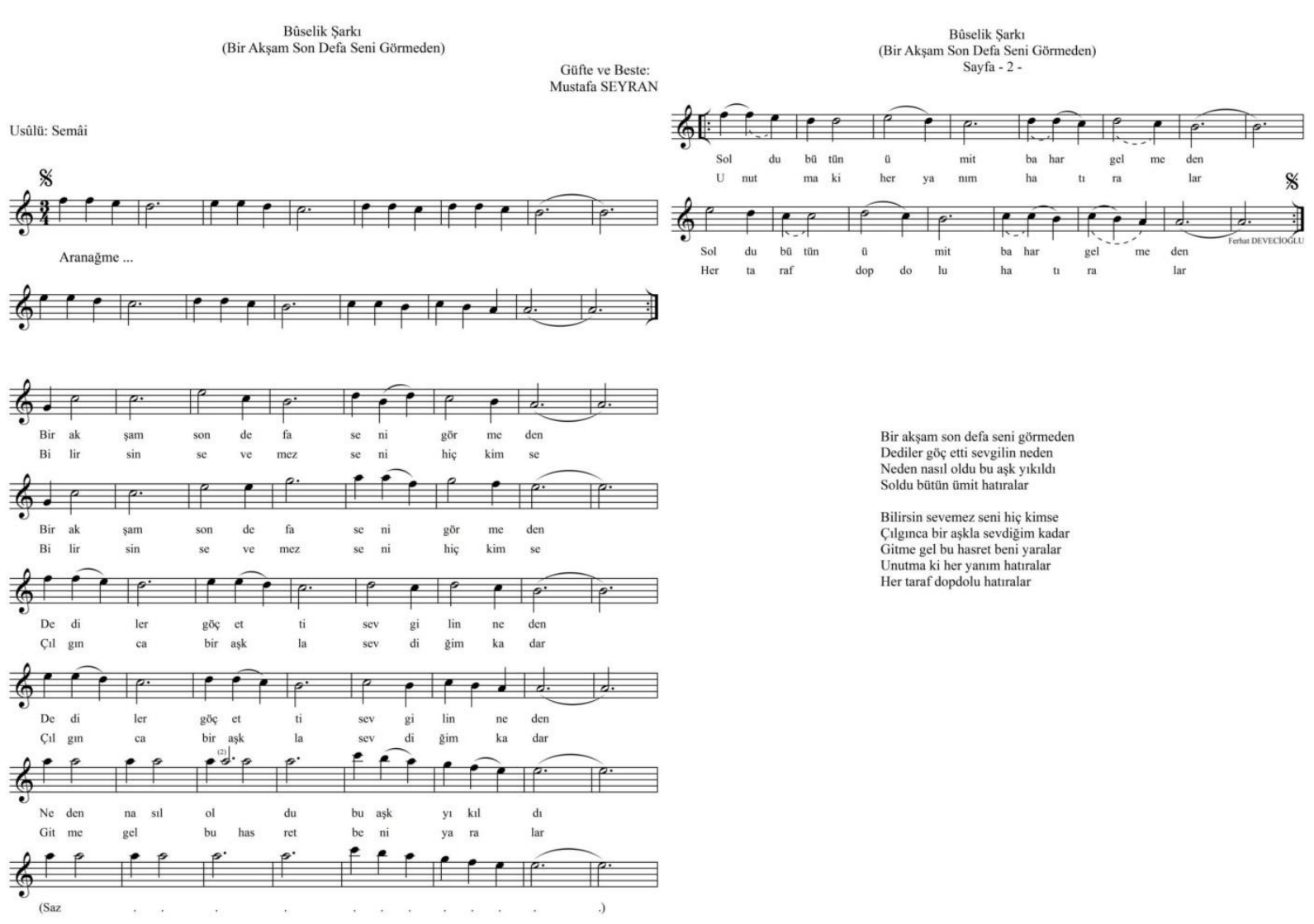

Şekil 2.1. Bir Akşam Son Defa Seni Görmeden sunulmuştur.

“Müzikal ve Teknik Becerilere İlişkin Performans Değerlendirme Ölçeği” Şekil 2. 2.`de

\begin{tabular}{|c|c|c|c|c|c|c|}
\hline \multicolumn{7}{|c|}{ Müzikal ve Teknik Becerilere liliłkin Performans Değgerlendirme Öltegeği } \\
\hline \multicolumn{7}{|c|}{\begin{tabular}{l|l} 
Test Asamast \\
Ö́rencinin Ad ve Soyadı \\
Uzzan Ad ve Soyadt \\
Eser Adt
\end{tabular}} \\
\hline \multirow[b]{2}{*}{ Daramstar } & \multicolumn{5}{|c|}{ Ölkit } & \multirow[b]{2}{*}{ Allman Paan } \\
\hline & 20 Puan & 15 puan & 10 puan & ${ }_{5}^{\text {Pran }}$ & op puan & \\
\hline 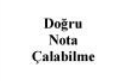 & 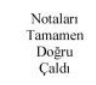 & 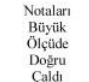 & 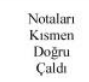 & 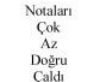 & $\begin{array}{c}\text { Noablar } \\
\text { Dofiru } \\
\text { Calimad }\end{array}$ & \\
\hline 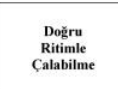 & 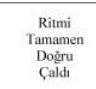 & 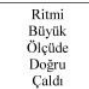 & 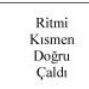 & 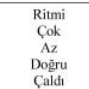 & 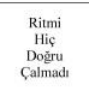 & \\
\hline 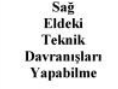 & 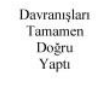 & 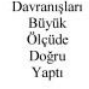 & 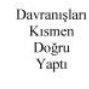 & 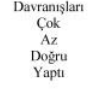 & 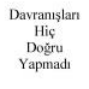 & \\
\hline 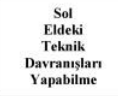 & 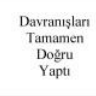 & 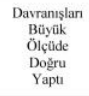 & 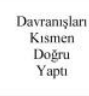 & 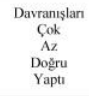 & 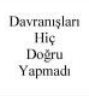 & \\
\hline 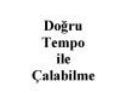 & 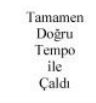 & 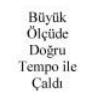 & 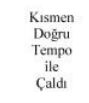 & 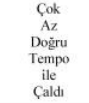 & 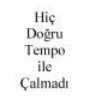 & \\
\hline 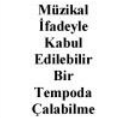 & 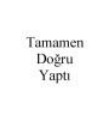 & 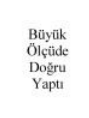 & 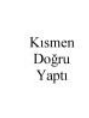 & 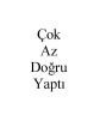 & 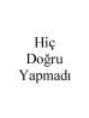 & \\
\hline & & & & & Topham & \\
\hline
\end{tabular}

Şekil 2.2. Mürikal ve Teknik Becerilere Ilişskin Performans Değerlendirme Ölçeği (Devecioğlu, 2017, s. 306). 

kullanılabilirlik düzeylerinin belirlenmesi. Journal of Human Sciences, 17(2), 432-457. doi:10.14687/jhs.v17i2.5788

\subsection{2 Ön Test ve Son Test}

Bu süreçte ilk olarak çalışma grubu öğrencilerine ön test aşaması uygulanmıştır. 8 haftalık deneysel işlem sürecinden sonra ön test aşamasında kullanılan sorulara hiçbir müdahale edilemeden son test aşaması uygulanmıştır. Öğrencilerin tüm aşamalara ait performans içerikli video kayıtları gerçekleştirilerek alanında uzman keman eğitimcilerine sunulmuş ve değerlendirmeleri yapılmıştır. Elde edilen veriler "Statistical Package for the Social Sciences 20" (SPSS 20) paket programina aktarılmışır.

\subsubsection{1 Ön Test ve Son Test Sorusu}

Çalışma grubu öğrencilerinden Refik FERSAN'a ait 4 hâne ve 1 mülâzime (teslim) hânesinden oluşan, hafiff usûlünde (32/4) bestelenen "Rast Peşrev" adlı eseri seslendirmeleri istenmiştir. Eser, hiçbir değişikliğe uğratılmadan "Finale 2014" nota yazım programına aktarılarak sağ ve sol el tekniklerini içeren bir yapıda yazılmıştır. Bu süreç; konum, arşeleme ve parmak numaraları gibi öğeler dikkate alınarak gerçekleştirilmiştir. Ezgi bütünlüğünün sağlanabilmesi için arşelemeyle (sağ el) birlikte birinci ve üçüncü konumlar (sol el) uygulanmıştır. Eser, Şekil 2. 3. ve 2. 4.'te sunulmuştur. 
Uludağ, A. K., \& Devecioğlu, F. (2020). Batı müziği keman icracılığ1 tekniklerinin Türk müziği keman öğretimi alanında kullanilabilirlik düzeylerinin belirlenmesi. Journal of Human Sciences, 17(2), 432-457. doi:10.14687/jhs.v17i2.5788

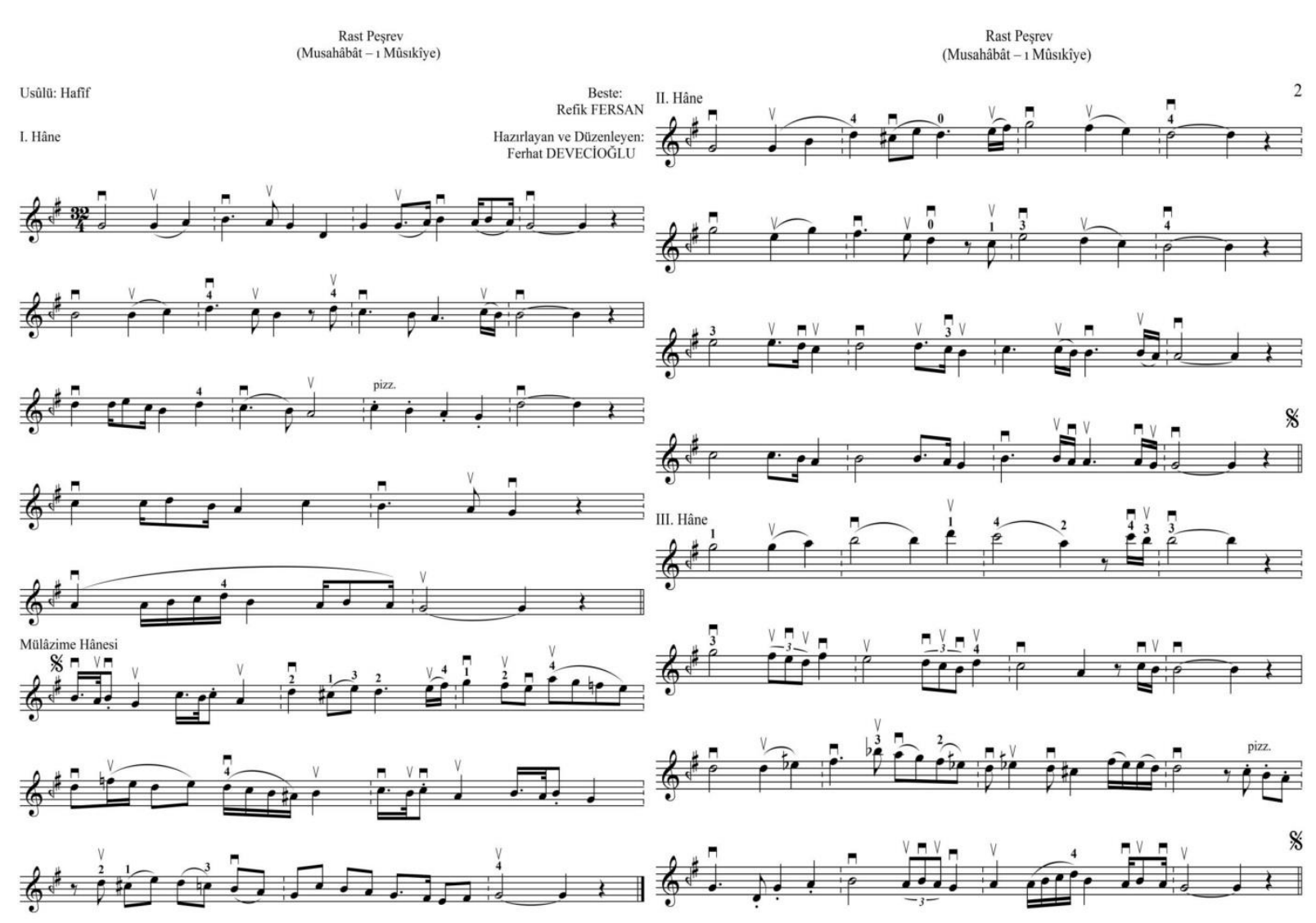

Şekil 2.3. Rast Peşrev (Sayfa 001 ve 002)

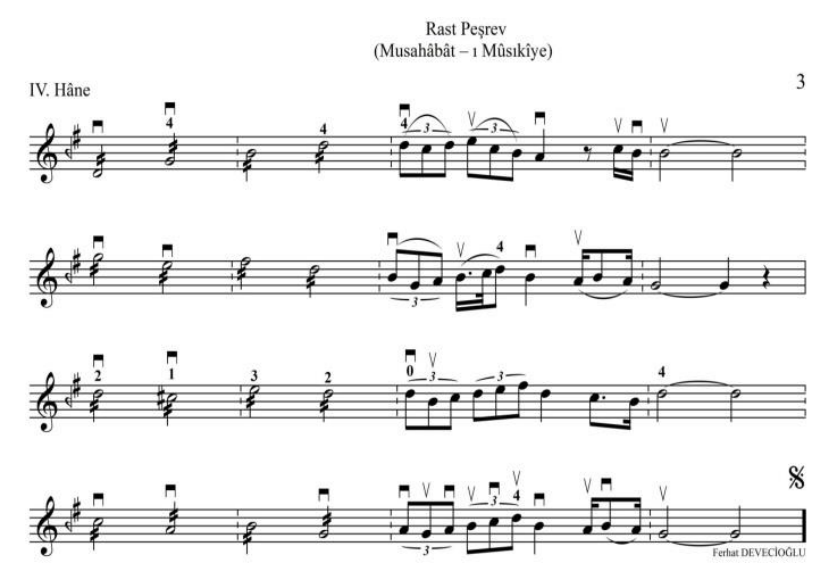

Şekil 2.4. Rast Peşrev (Sayfa 003)

$\mathrm{Bu}$ süreçte çalışma grubu öğrencilerine "peşrev türündeki bir eseri keman çalgısıyla seslendirebilme?” başlığı altında aşağıda ki 6 adet soru yöneltilmiştir;

1. Doğru nota çalabilme?

2. Doğru ritimle çalabilme?

3. Sağ eldeki teknik davranışları yapabilme?

4. Sol eldeki teknik davranışları yapabilme?

5. Doğru tempo ile çalabilme?

6. Müzikal ifadeyle kabul edilebilir bir tempoda çalabilme?

\subsection{Geçerlilik ve Güvenirlilik Testi}

Denklik testinde, ön test ve son test aşamalarında performansların ölçme ve değerlendirmenin yapılabilmesi için Parasız (2009) ait bir çalışmada geliştirilen "Müzikal ve Teknik Becerilere İlişkin Performans Değerlendirme Ölçeği” kullanılmıştır. Bu ölçek beşli likert biçiminde 
Uludağ, A. K., \& Devecioğlu, F. (2020). Batı müziği keman icracılığ1 tekniklerinin Türk müziği keman öğretimi alanında kullanılabilirlik düzeylerinin belirlenmesi. Journal of Human Sciences, 17(2), 432-457. doi:10.14687/ihs.v17i2.5788

hazırlamışır. Bu ölçekteki soruların geçerlilik ve güvenirliği tespit etmek amacıyla Cronbach`s Alpha test istatistiğini kullanmış ve güvenirliği belirlenmiştir. Bu ölçeğe ait geçerlilik ve güvenirlik testi Tablo 2. 1. ¿de sunulmuştur.

Tablo 2.1. Mü̈rikal ve Teknik Becerilere İlişkin Performans Değerlendirme Ölçeğinin Geçerlilik ve Güvenirlik Testi (Devecioğh, 2017, s. 92).

\begin{tabular}{cc}
\hline Cronbach`s Alpha & N of Items \\
\hline 0,792 & 6 \\
\hline & Cronbach`s Alpha \\
\hline Doğru Nota Çalabilme & 0,802 \\
Doğru Ritimle Çalabilme & 0,778 \\
Sağ Eldeki Teknik Davranışları Yapabilme & 0,745 \\
Sol Eldeki Teknik Davranısları Yapabilme & 0,703 \\
Müzikal İfade ve Tempo & 0,747 \\
\hline Toplam Kriter Puanı & 0,800 \\
\hline
\end{tabular}

\subsection{Verilerin Analizi}

Verilerin analizinde "SPSS 20" paket programı kullanılmıştır. Çalışma gruplarında dörder kişi bulunduğu için analizlerde parametrik olmayan testlerden yararlanılmıştır. Araştırmalarda örneklem oluşturan grupların büyüklügünün 15 in altında olduğu durumlarda parametrik olmayan testlerin kullanılması bir zorunluluktur (Büyüköztürk, 2010, s. 8). Buna göre katılımcıların ön test ve son test sonuçları arasında anlamlı bir fark olup olmadığını belirlemek amacıyla "Mann - Whitney U Testi” kullanılmıştır. Büyüköztürk'e (2010) göre bu test, iki ilişkisiz örneklemden elde edilen puanların birbirlerinden anlamlı bir şekilde farklıllk gösterip göstermediğini test etmek için kullanılmaktadır. Verilerin çözümlenmesinde 0.05 önem düzeyi olarak kabul edilmiştir.

\subsection{Deneysel İşlem}

Bu süreç, olabildiğince sistematik ve konunun amacına uygun bir biçimde yapılandırılmıştır. Yapılan uygulamalar, toplam 8 hafta ve 4 ders saatinden oluşmaktadır. Bir ders saatinin süresi 45 dakika olarak belirlenmiştir. Bu süreci kapsayan çalışmalar deney grubuna aktarılmıs, kontrol grubuna ise geleneksel ders işleyiş yöntemleri uygulanmıştır. Deneysel işlem kodlarının sıralaması; basitten karmaşığa, bilinenden bilinmeyene, somuttan soyuta biçiminde "Doğrusal (Lineer) Yaklaşımına göre hazırlanmıştır. Bu bölümü kapsayan tüm çalışmalar ve eserler, öğrencilerin çalg1 beceri düzeylerine uygun bir biçimde hazırlanmıştır.

Oluşturulan 15 farklı kod, hem araştırmacıya hem de yapılan uygulamalarda karışıklığa yol açmaması için kullanılarak; çalışmaların, etütlerin ve eserlerin haftalara bölünmesi yoluyla hazırlanmiştır.

\subsubsection{Deneysel İşlem Kodları ve Uygulanış Biçimleri}

$\mathrm{Bu}$ kodlara ait tüm açıklamalar alt başlıklar biçiminde belirtilmiştir. Ayrıca sisteme ait uygulamanın zaman çizelgesi Tablo 2. 2. 'de sunulmuştur. 
Uludağ, A. K., \& Devecioğlu, F. (2020). Batı müziği keman icracıllğı tekniklerinin Türk müziği keman öğretimi alanında kullanılabilirlik düzeylerinin belirlenmesi. Journal of Human Sciences, 17(2), 432-457. doi:10.14687/jhs.v17i2.5788

Tablo 2.2. Deneysel Işslem Kodlarmm Uygulanacă̆ı Ders Haftalar (Devecioğlu, 2017, s. 105).

\begin{tabular}{|c|c|c|}
\hline $\begin{array}{c}\text { İşlenecek } \\
\text { Ders } \\
\text { Haftaları }\end{array}$ & $\begin{array}{c}\text { Deneysel } \\
\text { İşlem } \\
\text { Kodu } \\
\end{array}$ & Deneysel İşlem Kodu Açıklamaları \\
\hline 1. 2. & 1 & Türk Müziğinde Perdeler (Ses) \\
\hline 1. 2 . & 2 & $\begin{array}{l}\text { Türk Müziğinde Makamları Meydana Getiren Özel Tam } \\
\text { Dörtlüler }\end{array}$ \\
\hline 1. 2. & 3 & $\begin{array}{l}\text { Türk Müziğinde Makamları Meydana Getiren Özel Tam } \\
\text { Beşliler }\end{array}$ \\
\hline 1. 2.3. & 4 & Türk Müziğinde Makam Dizileri \\
\hline 1. 2.3 . & 5 & Arpejler \\
\hline 2. 3.4 . & 6 & Türk Müziğinde Makam Dizileri (İki Oktav) \\
\hline 2. 3.4. & 7 & Türk Müziği Makam Dizilerinde Arpejler (İki Oktav) \\
\hline 3. 4. 5.6.7.8. & 8 & $\begin{array}{l}\text { Türk Müziğinde Makam Dizileri (İki Oktav ve Konum } \\
\text { Geçişli) }\end{array}$ \\
\hline 3. 4. 5.6.7.8. & 9 & $\begin{array}{l}\text { Türk Müziği Makam Dizilerinde Arpejler (İki Oktav ve } \\
\text { Konum Geçişli) }\end{array}$ \\
\hline 3. 4 . & 10 & Dört Ölçülük Tonal Ezgi \\
\hline 3. 4. & 11 & Dört Ölçülük Makamsal Ezgi \\
\hline 4. 5.6. 7. & 12 & Sekiz Ölçülük Makamsal Ezgi \\
\hline 4. 5.6.7.8. & 13 & Şark1 Türünden Eserler \\
\hline 4. 5.6.7.8. & 14 & Peşrev Türünden Eserler \\
\hline 4. 5.6.7.8. & 15 & Saz Semâi Türünden Eserler \\
\hline
\end{tabular}


Uludağ, A. K., \& Devecioğlu, F. (2020). Batı müziği keman icracıllğı tekniklerinin Türk müziği keman öğretimi alanında kullanılabilirlik düzeylerinin belirlenmesi. Journal of Human Sciences, 17(2), 432-457. doi:10.14687/jhs.v17i2.5788

\subsubsection{Türk Müziğinde Perdeler (Ses)}

1. deneysel işlem kodunda, Türk müziğinde perde çalısmalarından oluşmaktadır. $\mathrm{Bu}$ çalışmada, öğrencilerden perdelerin yazılı belge üzerinden gösterilerek veya sözel bir biçimde perde isimleri söylenerek keman çalgisında seslendirmeleri istenmiştir. Bu uygulama sadece 1. Konum ile sinırlandırılmıştır.

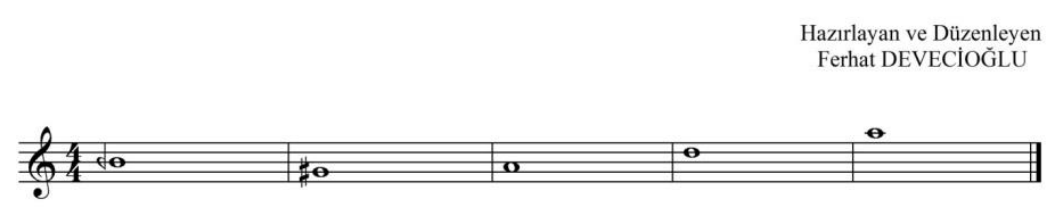

Şekil 2.5. Keman Calgisinda Perde Cahısmalar

\subsubsection{Türk Müziğinde Makamları Meydana Getiren Özel Tam Dörtlüler}

2. deneysel işlem kodunda, Türk müziğinde makamları meydana getiren özel tam dörtlü çalışmaları, 4 farklı basit makamların (çârgâh, kürdî, rast ve bûselik) özel dörtlülerinden oluşmaktadır. Bu çalışmada, öğrencilerden sağ ve sol el tekniklerini uygulamaları istenmiş ve bir tek 1. konum kullanılmıştır.

Türk Müziğinde Makamları Meydana Getiren Özel Tam Dörtlü Çalışmaları

(Çârgâh Dörtlüsü) Deneysel İșlem Kodu: 2. 1.

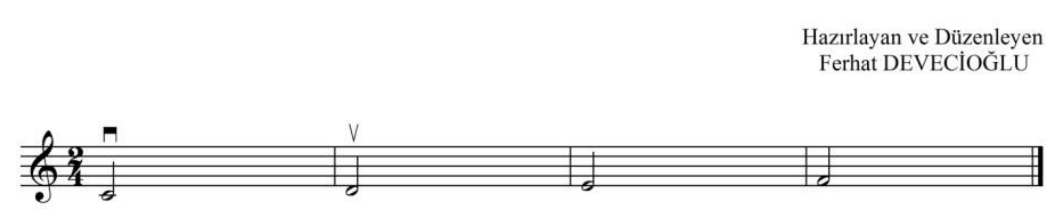

Şekil 2.6. Keman Çalgısında Tam Dörtlü Çalısmaları (Çârgâh Dörtlüsü)

\subsubsection{Türk Müziğinde Makamları Meydana Getiren Özel Tam Beşliler}

3. deneysel işlem kodunda, Türk müziğinde makamları meydana getiren özel tam beşli çalışmaları, 4 farklı basit makamların (hicaz, hüseynî, rast ve çârgâh) özel beşlilerinden oluşturulmuş ve öğrencilerden sağ ve sol el tekniklerini uygulamaları istenmiştir. Bir önceki uygulamalarda olduğu gibi 1. konum kullanılmışır.

Türk Müziğinde Makamları Meydana Getiren Özel Tam Beşli Çalışmaları

(Hicaz Beșlisi) Deneysel İșlem Kodu: 3.1.

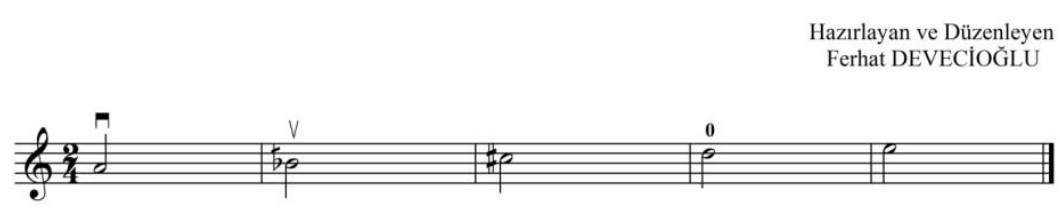

Şekil 2.7. Keman Çalgısında Tam Beşli Calısmalar (Hicaz Beşlisi) 
Uludağ, A. K., \& Devecioğlu, F. (2020). Batı müziği keman icracıllğı tekniklerinin Türk müziği keman öğretimi alanında kullanılabilirlik düzeylerinin belirlenmesi. Journal of Human Sciences, 17(2), 432-457. doi:10.14687/jhs.v17i2.5788

\subsubsection{Türk Müziğinde Makam Dizileri}

4. deneysel işlem kodunda ise 5 farklı makam (bûselik, nihâvend, acem aşîrân, kürdî ve kürdî‘li hicazkâr) dizisine ve 1 oktav içerisinde yer alan inici çalışmalara 1. konum eşliğinde yer verilmiştir. Aynı zamanda öğrencilerden sağ ve sol el tekniklerini uygulamaları istenmiştir.

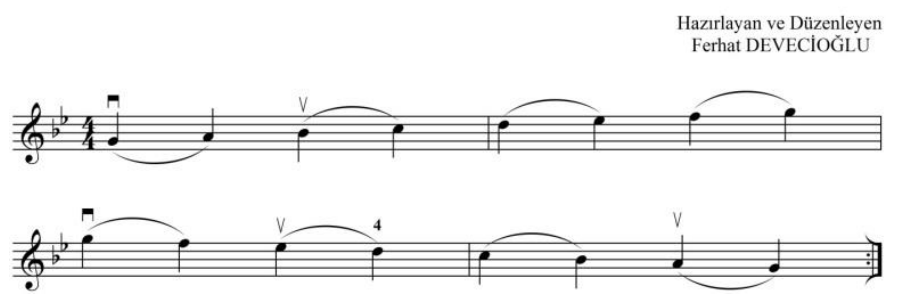

Şekil 2.8. Keman Çalgısında Diæ̧i Callşmaları (Nihâvend Makamı)

\subsubsection{Türk Müziği Makam Dizilerinde Arpejler}

5. deneysel işlem kodunda arpej çalışmaları yapılmıştır. Bu uygulama, 2 farklı makam (bûselik ve çârgâh) dizisiyle birlikte 1 oktavı kapsayacak şekilde inici ve çıkıcı biçimde seslendirilerek gerçekleştirilmiştir. Çalışma, hem sağ hem de sol el teknikleriyle birlikte birinci konumda uygulamıstır.

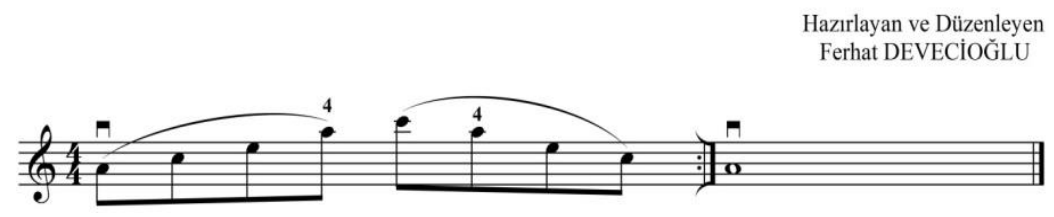

Şekil 2.9. Keman Çalgısında Arpej Çalışmaları (Bûselik Makamı)

\subsubsection{Türk Müziğinde Makam Dizileri (İki Oktav)}

6. deneysel işlem kodunu çârgâh ve ferahfezâ makam dizileri oluşturmuştur. Bir önceki uygulamada olduğu gibi çalışma, 2 oktav içerisinde, inici-çıkıcı biçimde, birinci konumda, sağ ve sol el tekniklerine dikkat edilerek seslendirilmiştir.

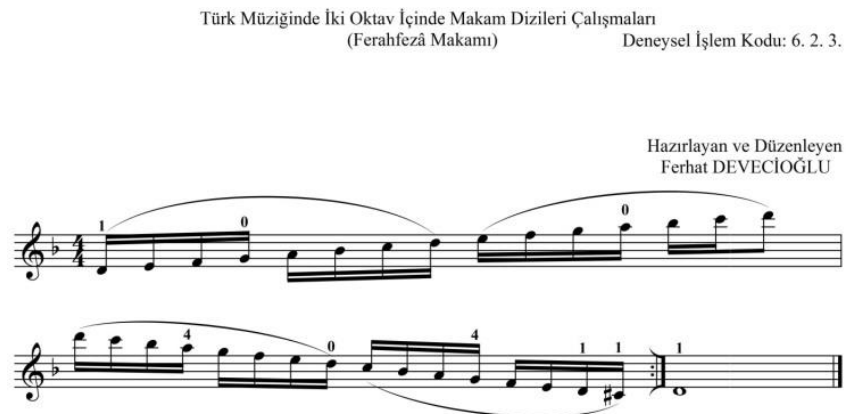

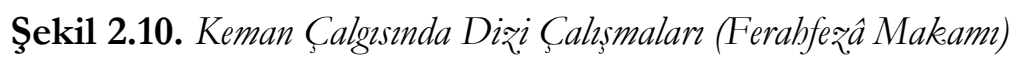


Uludağ, A. K., \& Devecioğlu, F. (2020). Batı müziği keman icracıllğı tekniklerinin Türk müziği keman öğretimi alanında kullanılabilirlik düzeylerinin belirlenmesi. Journal of Human Sciences, 17(2), 432-457. doi:10.14687/jhs.v17i2.5788

\subsubsection{Türk Müziği Makam Dizilerinde Arpejler (İki Oktav)}

7. deneysel işlem kodunda ki çalışmalar şu şekilde yapılmıştır: İlk olarak iki oktavı kapsayacak şekilde Çargah ve ferahnak makam dizilerinde hazırlanan arpej çalışmaları uygulanmıştır. Tüm kodlarda olduğu gibi öğrencilerin sağ ve sol el tekniklerine dikkat etmeleri istenmiştir.

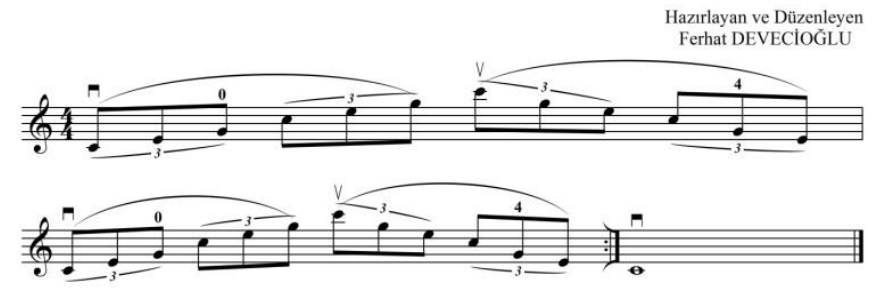

Şekil 2.11. Keman Çalgııında Arpej Çalıșmaları (Çârgâh Makamı)

\subsubsection{Türk Müziğinde Makam Dizileri (İki Oktav ve Konum Geçişli)}

8. deneysel işlem kodunda farklı olarak; acem aşîân, rast ve nihâvend olmak üzere üç farklı makam dizisi kullanılmıştır. Diğer bir fark, birinci ve üçüncü konumların kullanılmasıyla dikkat çekmektedir. Diğer uygulamalarla benzerlik gösteren noktalar ise iki oktav içerisinde inici ve çıkıc1 biçimin kullanılması ve öğrencilerden sağ ve sol el tekniklerini uygulama zorunluluğudur.

Türk Müziğinde Íki Oktav Iç̣inde Makam Dizileri Çalıșmaları (Rast Makamı) Deneysel Ișlem Kodu: 8. 2.1.

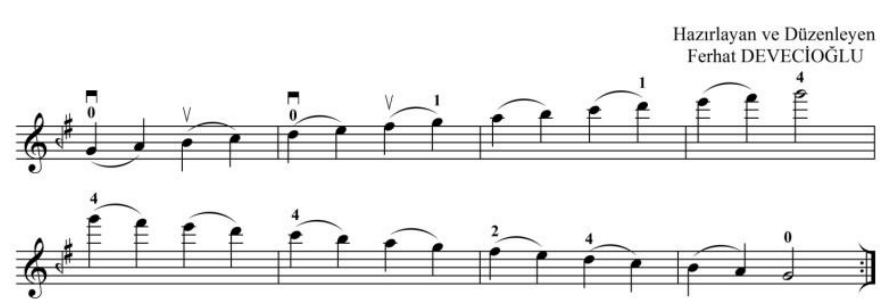

Şekil 2.12. Keman Calgısında Dį̧i Calısmalar (Rast Makamı)

\subsubsection{Türk Müziği Makam Dizilerinde Arpejler (İki Oktav ve Konum Geçişli)}

9. kod içerisinde farklı olarak mâhûr makamı dizisine yer verilmiştir. Bir önceki çalışmada olduğu gibi nihâvend makamı dizisi tekrar kullanılmıştır. Dizi icraları aynı şekilde iki oktav içerisinde inici ve çıkıcı biçiminde hazırlanmıştır. Diğer uygulamada ki gibi, 1. ve 3. konum kullanılarak sağ ve sol el tekniklerine dikkat edilmiştir.

Türk Müziği Makam Dizilerinde İki Oktav Içinde Arpej Çalışmaları

(Mâhûr Makamı) Deneysel İșlem Kodu: 9. 1.2.

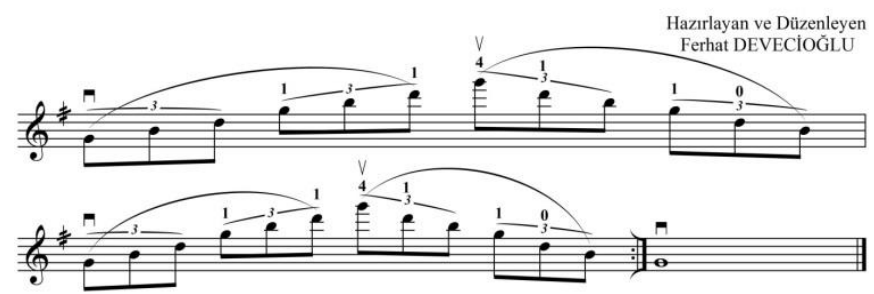

Şekil 2.13. Keman Çalgısında Arpej Calıșmaları (Mâbûr Makamı) 
Uludağ, A. K., \& Devecioğlu, F. (2020). Batı müziği keman icracıllğı tekniklerinin Türk müziği keman öğretimi alanında kullanılabilirlik düzeylerinin belirlenmesi. Journal of Human Sciences, 17(2), 432-457. doi:10.14687/jhs.v17i2.5788

\subsubsection{Dört Ölçülük Tonal Ezgi}

Deneysel işlem sürecinin 10. kodunu tonal içerikli ezgi seslendirmesi kapsamaktadır. Tonlar; sol majör, do majör ve ilgili minör tonları kullanılarak belirlenmiştir. Çalışmalar; 4 ölçülük ezgiler halinde, 4/4, 3/4 ve 2/4 lük ritim kalıplarılla yazılmıştır. Keman üzerinde birinci ve üçüncü konumlar kullanılmış, öğrencilerden sağ ve sol el tekniklerini uygulamaları istenmiştir.

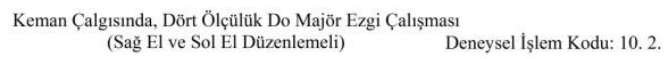

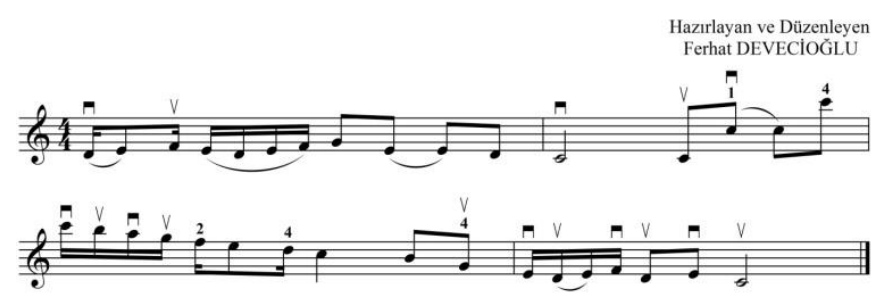

Şekil 2.14. Keman Calgısında Ę̧gi Çalısmalar (Do Majör)

\subsubsection{Dört Ölçülük Makamsal Ezgi}

Uygulama sürecinin 11. deneysel işlem kodunda nihâvend, hicaz ve ferahfez makamlarında dörder ölçülük ezgiler seslendirilmiştir. Bu ezgiler, sengin semâi (6/4), düyek (8/8) ve curcuna (10/8) usullerinden oluşmuştur. Keman üzerinde birinci ve üçüncü konumlar kullanılmıştır. Tüm çalışma etaplarında olduğu gibi öğrenciler, sağ ve sol el tekniklerini uygulamışlardır.

Keman Çalgısında, Dört Ölçülük Hicaz Makamında Ezgi Çalışması

(Sağ El ve Sol El Düzenlemeli) Deneysel Ișlem Kodu: 11. 2.

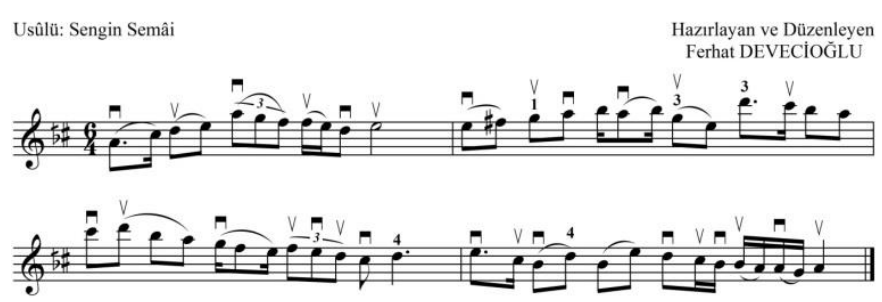

Şekil 2.15. Keman Çalgısında Eฉ̨gi Çalısmaları (Hicą Makamı) 
Uludağ, A. K., \& Devecioğlu, F. (2020). Batı müziği keman icracılığ1 tekniklerinin Türk müziği keman öğretimi alanında kullanılabilirlik düzeylerinin belirlenmesi. Journal of Human Sciences, 17(2), 432-457. doi:10.14687/jhs.v17i2.5788

\subsubsection{Sekiz Ölçülük Makamsal Ezgi}

Deneysel işlem sürecinin 12. deneysel işlem kodunda, makamsal ezgi seslendirilmesinde, kürdî, çârgâh, mâhûr, bûselik ve hicaz makamlarında 8 ölçülük ezgiler çalışılmıştır. Bu ezgilerde, sofyân (4/4), Türk aksağ1 (5/8), yürük semâi (6/8), devr - i hindî (7/4) ve düyek (8/8) usûlleri kullanılmıştır. Aynı şekilde birinci ve üçüncü konumlandırmalara yer verilmiş ve öğrencilerden sağ ve sol el tekniklerini uygulamaları istenmiştir.

Keman Çalgısında, Sekiz Ölçüluak Bûselik Makamında Ezgi Çalışması

(Sağ El ve Sol El Düzenlemeli) Deneysel İșlem Kodu: 12.5.

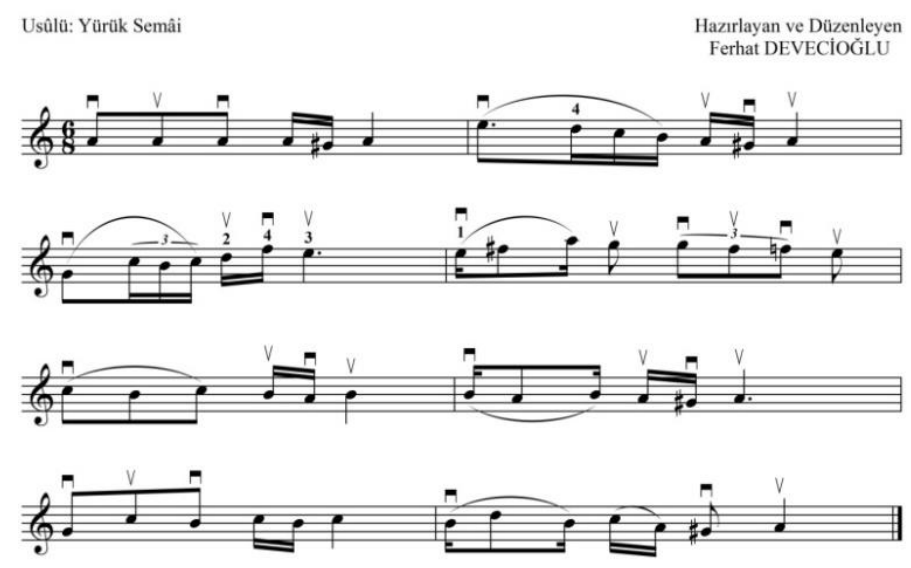

Şekil 2.16. Keman Çalgısında Eq̧i Çalısmaları (Bûselik Makamı) 
Uludağ, A. K., \& Devecioğlu, F. (2020). Batı müziği keman icracılığ1 tekniklerinin Türk müziği keman öğretimi alanında kullanılabilirlik düzeylerinin belirlenmesi. Journal of Human Sciences, 17(2), 432-457. doi:10.14687/jhs.v17i2.5788

\subsubsection{3 Şarkı Türünden Eserler}

Bu aşamayı 13. deneysel işlem kodu oluşturmaktadır. Diğer uygulamalardan farklı olarak 6 adet şarkı türündeki eserlerin seslendirilmesi yapılmıştır. Düzenlemeler yapılırken hem sağ hem de sol el teknikleri kullanılmış ve eserin asıl yapısını bozacak müdahalelerde bulunulmamıştır.
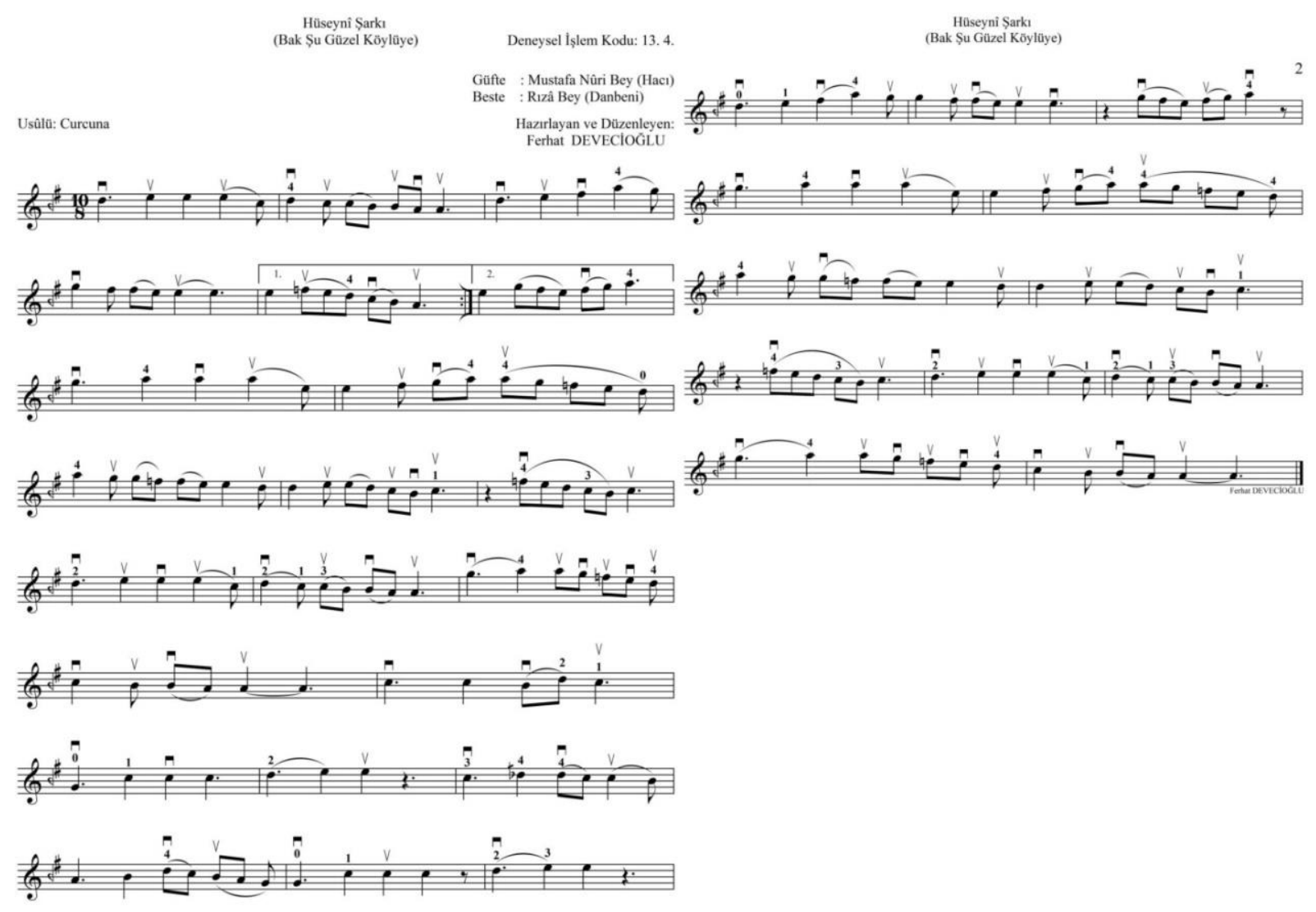

Şekil 2.17. Bak Şu Gü̊sel Köylïye 
Uludağ, A. K., \& Devecioğlu, F. (2020). Bat müziği keman icracılığı tekniklerinin Türk müziği keman öğretimi alanında kullanilabilirlik düzeylerinin belirlenmesi. Journal of Human Sciences, 17(2), 432-457. doi:10.14687/jhs.v17i2.5788

\subsubsection{Peşrev Türünden Eserler}

14. deneysel işlem koduna sahip bu süreçte ise 6 adet peşrev türündeki eserler seslendirilmiştir. Şarkı türü eserlerin düzenlenmesinde yapıldığ gibi peşrevlerin özgün yapısına müdahale edilmemiş ve sağ-sol el teknikleri uygulanmıştır.

$$
\text { Sûz - i Dil Peșrev }
$$

Usûlü: Devr - $\mathrm{i}$ Kebîr

L. Hâne
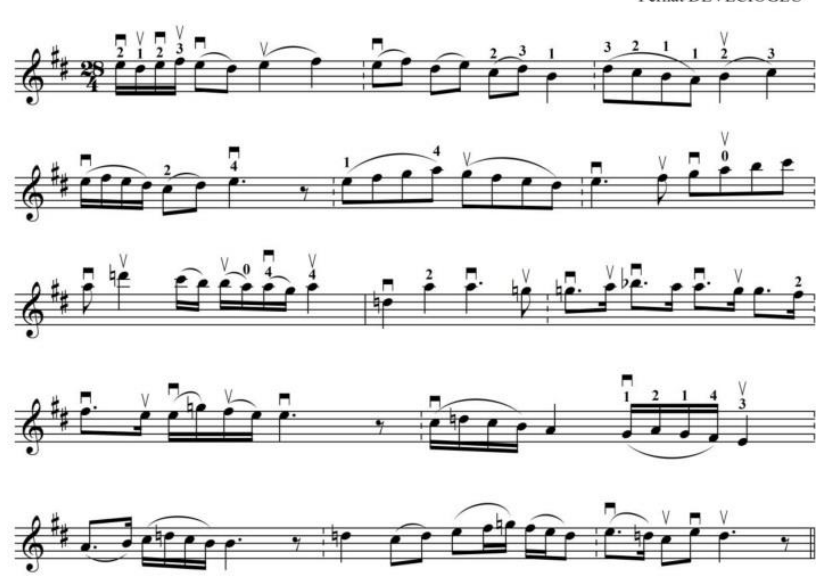
Mülâzime Hânesi
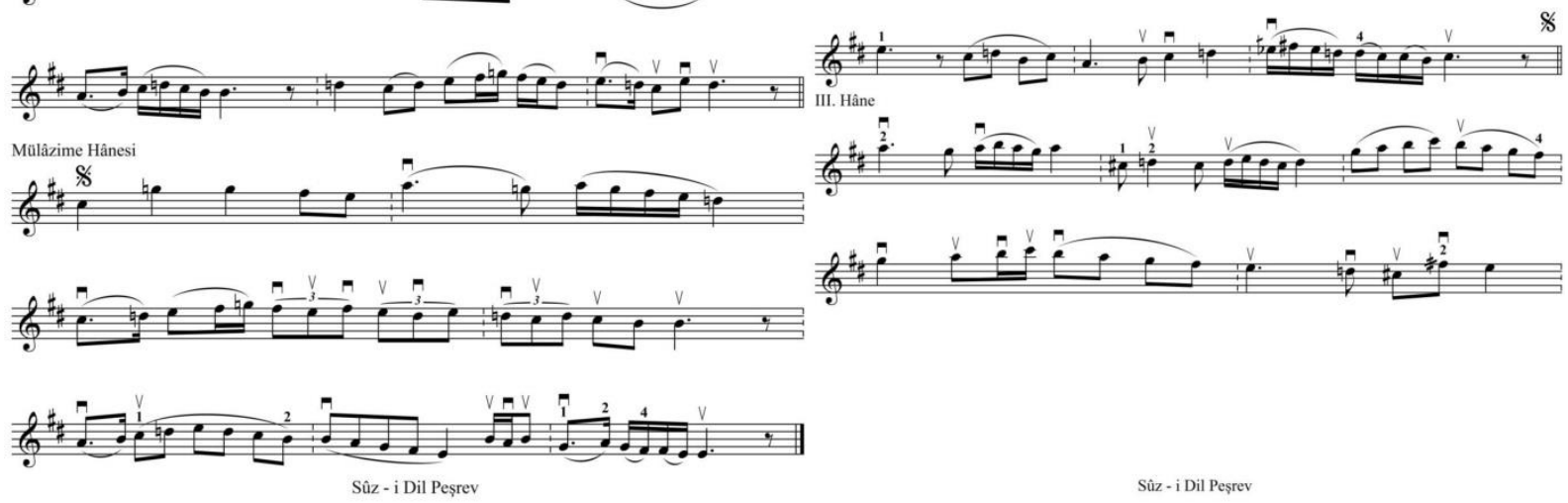
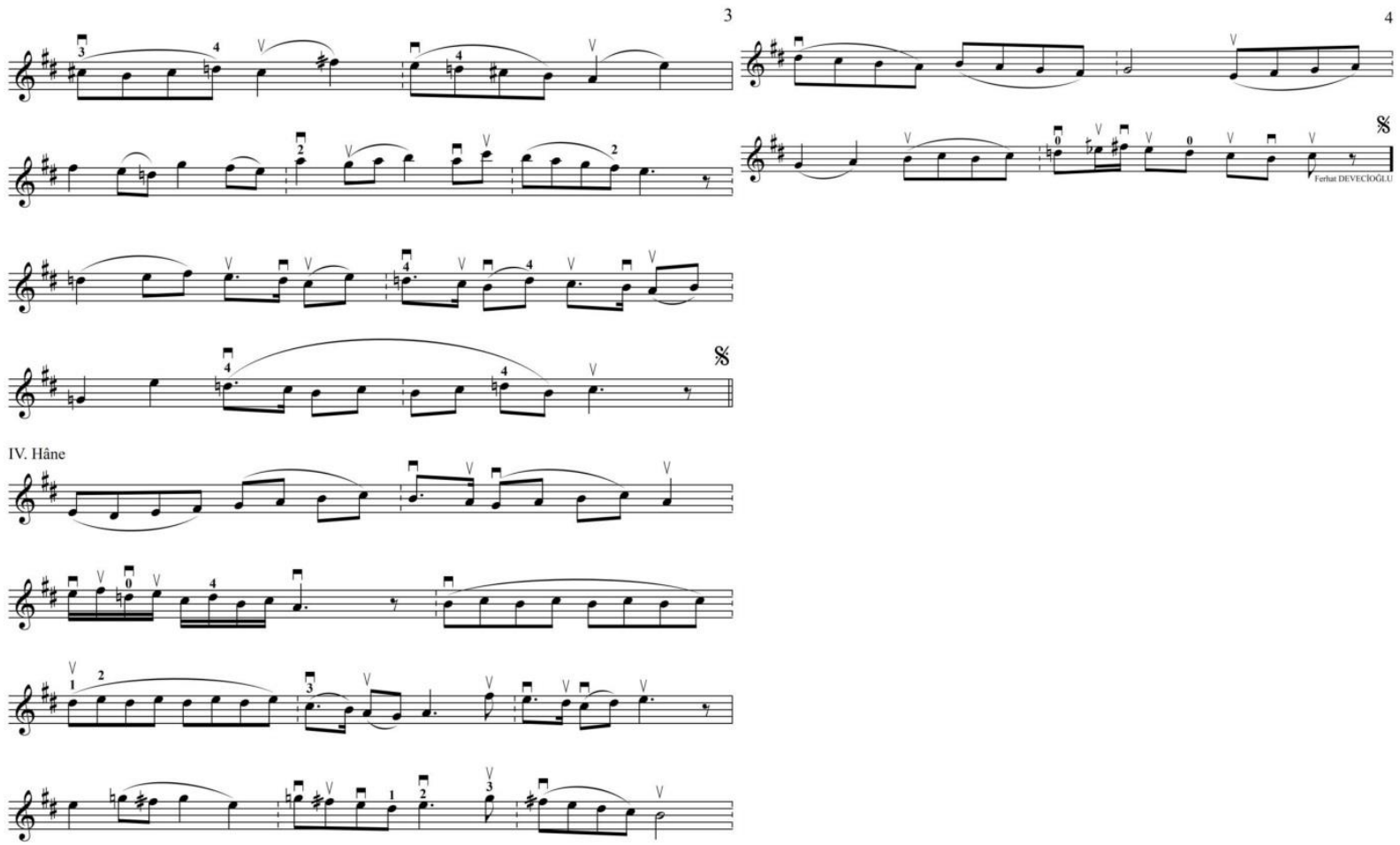

Şekil 2.18. Sûz - i Dil Peşrev 
Uludağ, A. K., \& Devecioğlu, F. (2020). Batı müziği keman icracılığ1 tekniklerinin Türk müziği keman öğretimi alanında kullanılabilirlik düzeylerinin belirlenmesi. Journal of Human Sciences, 17(2), 432-457. doi:10.14687/jhs.v17i2.5788

\subsubsection{Saz Semâi Türünden Eserler}

Deneysel işlem sürecinin son aşaması olan 15. işlem kodunda, 6 adet saz semâi türündeki eserler çalışılmıştır. Düzenlemeler gerçekleştirilirken diğer etaplarda olduğu gibi aynı yöntemler kullanilmiştır.

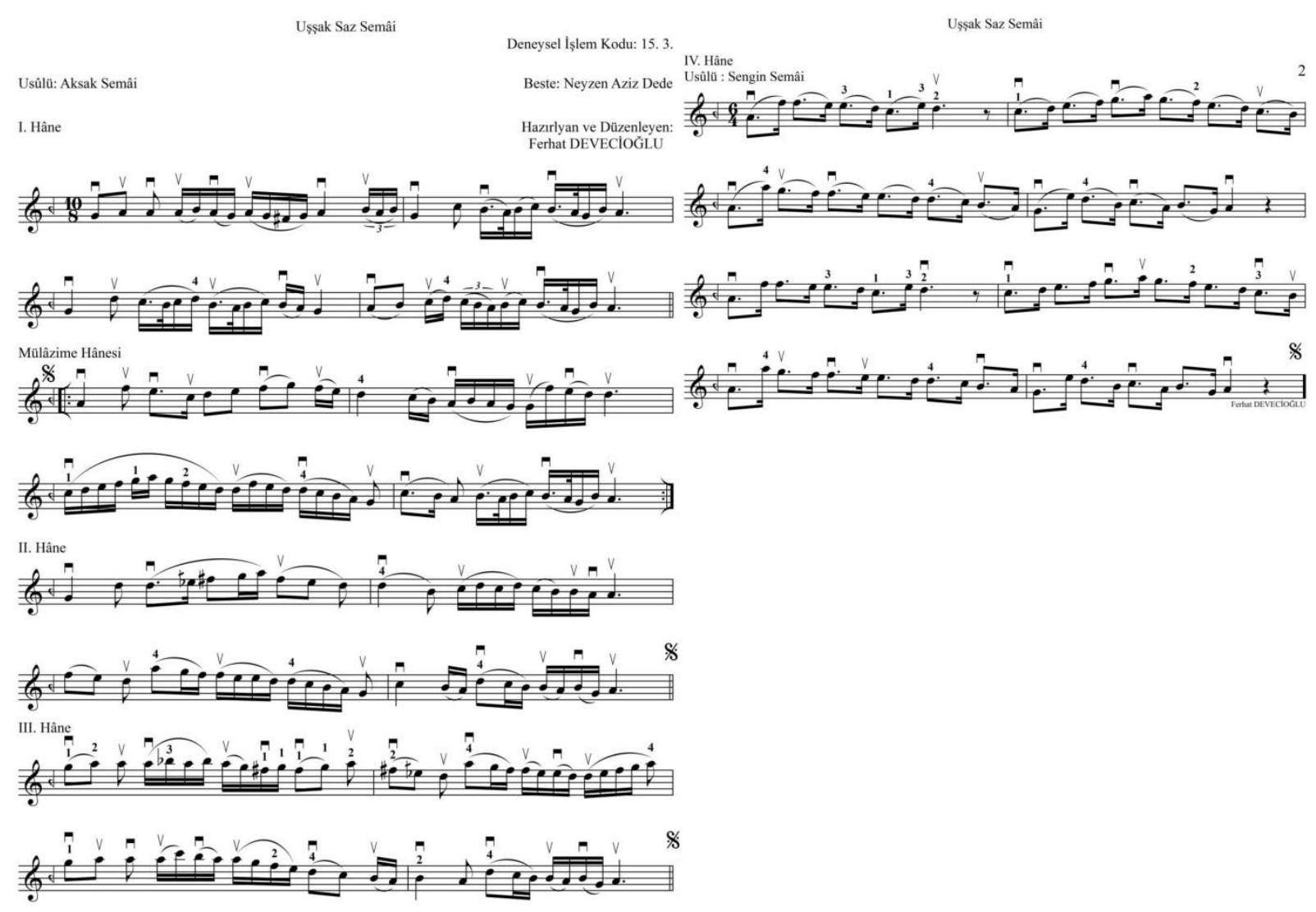

Şekil 2.19. Uşsak Saz Semâi

Ön test ve son test aşamalarını kapsayan tüm çalışmalarda kullanılan konumlar ve parmak numaralarının dizek (porte) üzerindeki notalarla eşleştirilmeleri Şekil 2. 20.`de ayrıntılı bir biçimde sunulmuştur. Bu şekillere ait renk ve işaretlerin açıklamaları da Tablo 2. 3. 'te görülmektedir. Parmak numaraları ve nota adları, Türk müziğinde kullanılan bolâhenk akorduna göre uyarlanmıştır. 

kullanılabilirlik düzeylerinin belirlenmesi. Journal of Human Sciences, 17(2), 432-457. doi:10.14687/jhs.v17i2.5788
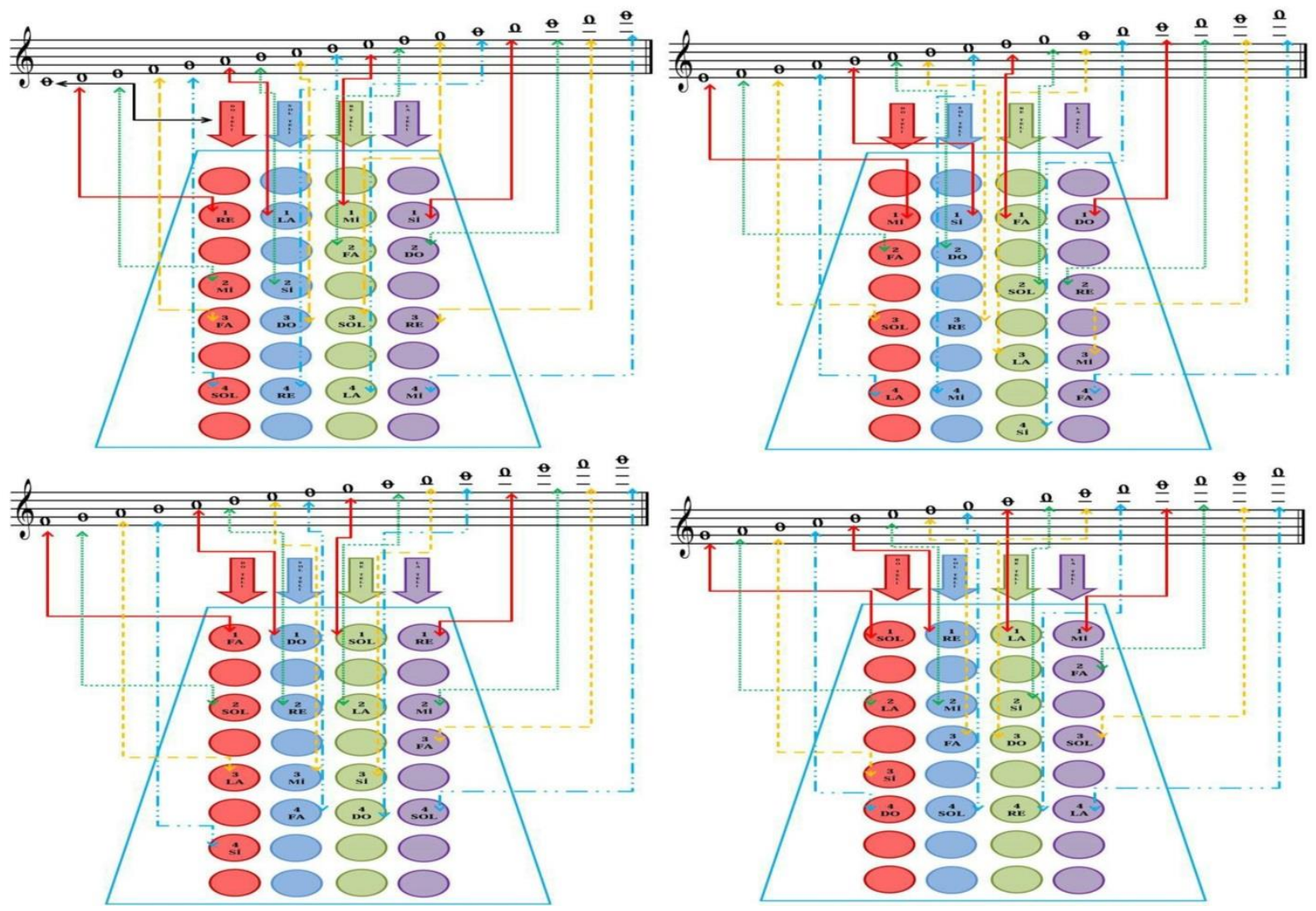

Şekil 2.20. Keman Calgismmn (Türk Mü̊iğinin Bolâhenk. Akordundaki) 1, 2, 3 ve 4 üncü Konum Di̊ggesindeki Nota Adlarmm Dį̧ek Üzerindeki Karşıllklar (Devecioğlu, 2017, s. 77 - 80).

Tablo 2.3. Konum Diə̌gesi Șekillerinde Kullanılan İsaretlerin Açılamalar (Devecioğlu, 2017, s. 81).

Şekiller Şekillerin Açıklaması

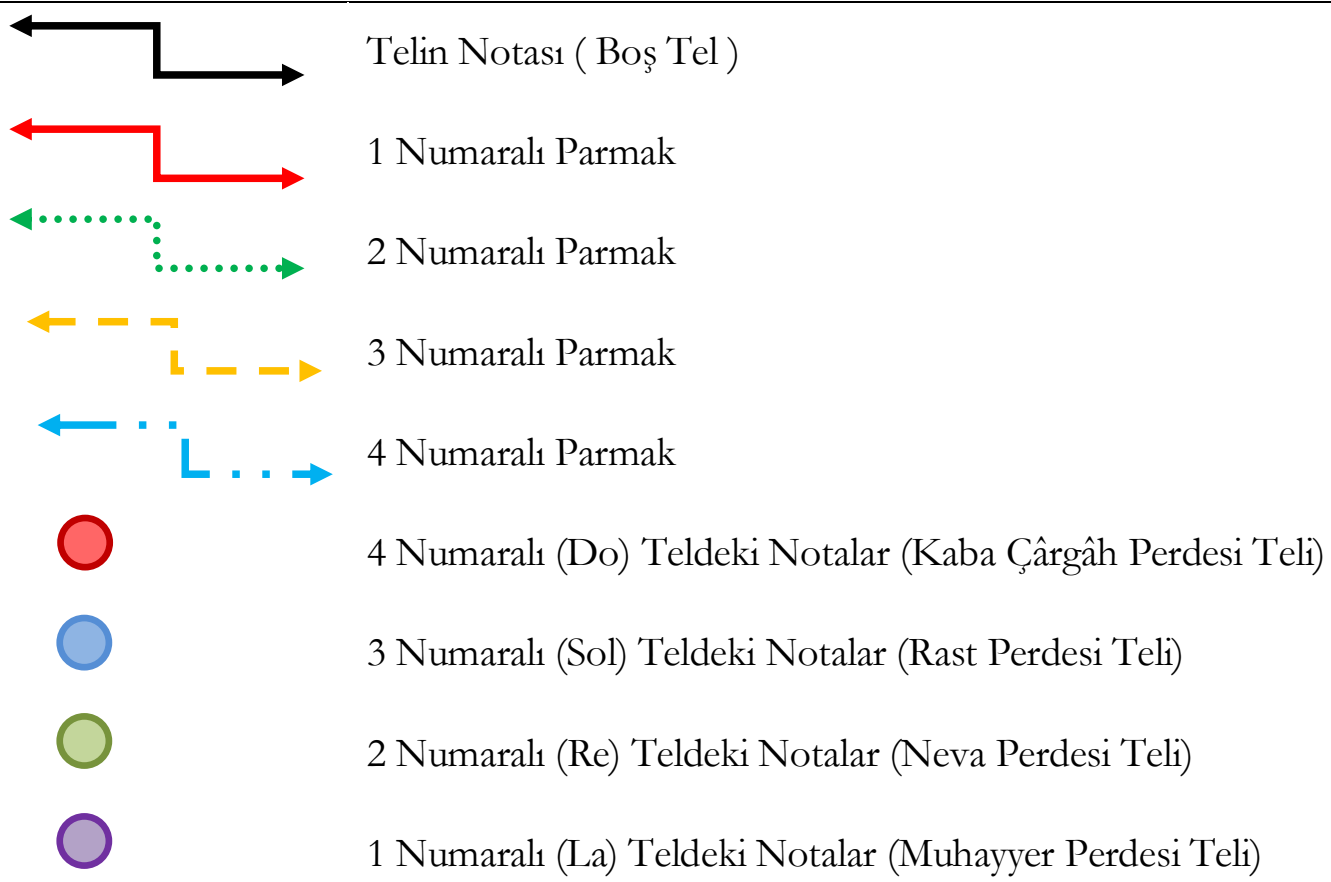


Uludağ, A. K., \& Devecioğlu, F. (2020). Batı müziği keman icracılığı tekniklerinin Türk müziği keman öğretimi alanında kullanılabilirlik düzeylerinin belirlenmesi. Journal of Human Sciences, 17(2), 432-457. doi:10.14687/jhs.v17i2.5788

\section{BULGULAR}

\subsection{Birinci Alt Probleme İlişkin Bulgular}

Öğrencilerin peşrev türündeki eserin notalarını doğru çalabilme becerilerinin test sonuçlarında istatistiksel yönden belirgin bir farkın var olduğunu veya olmadığını tespit edebilmek amaciyla Mann - Whitney U Testi uygulanmış ve sonuçlar tablo 3. 1.'de sunulmuştur.

Tablo 3.1. Deney ve kontrol grubunun pessrev türü eserinin notalarm doğru çalabilme becerilerine yönelik ön test puanlarma iliskin Mann - Whitney U Testi sonuclar

\begin{tabular}{lcccccc}
\hline Grup & $\mathbf{n}$ & Sira Ortalamas1 & Sira Toplami & U & Z & p \\
\hline Deney & 4 & 3.5 & 14 & 4.000 & -1.528 & .127 \\
Kontrol & 4 & 5.5 & 22 & & & \\
\hline Toplam & 8 & & & & & \\
\hline
\end{tabular}

Tablo 3. 1.`e göre kontrol ve deney grubu öğrencilerinin peşrev türündeki eserin notalarını doğru çalabilme becerilerine ilişkin puanlarında istatistiksel olarak belirgin bir fark tespit edilmemiştir. ( $\mathrm{U}=4,000 ; \mathrm{p}>0.05)$. Sıra ortalamaları incelendiğinde kontrol grubu öğrencilerinin deney grubu öğrencilerine göre peşrev türündeki eserin notalarını doğru nota çalabilme becerilerinden yüksek bir ortalamaya sahip oldukları anlaşılmaktadır. Bu sonucun istatistiksel açıdan önemli bir fark oluşturmadığı söylenebilir.

Öğrencilerin peşrev türündeki eserin notalarını doğru çalabilme becerileri tespit edilmiştir. Bu süreçte, Mann - Whitney U Testi uygulanmış ve istatistiksel açıdan belirgin bir farkın olup olmadığını gösteren sonuçlara tablo 3. 2.`de yer verilmiştir.

Tablo 3.2. Deney ve kontrol grubunun peşrev türü eserinin notalarm doğgu çalabilme becerilerine yönelik son test puanlarna iliskin Mann - Whitney U Testi sonuclar

\begin{tabular}{lcccccc}
\hline Grup & $\mathbf{n}$ & S1ra Ortalamas1 & S1ra Toplami & U & Z & p \\
\hline Deney & 4 & 5 & 20 & 6.000 & -.667 & .505 \\
Kontrol & 4 & 4 & 16 & & & \\
\hline Toplam & 8 & & & & & \\
\hline
\end{tabular}

Tablo 3. 2. ye göre kontrol ve deney grubu öğrencilerinin peşrev türündeki eserin notalarını doğru çalabilme becerilerine yönelik son test puanlarında istatistiksel olarak belirgin bir farka ulaşılmamışır $(\mathrm{U}=6,000 ; \mathrm{p}>0.05)$. Sıra ortalamaları ise deney grubu öğrencilerinin peşrev türündeki eserin notalarını doğru çalabilme becerileri bakımından yüksek bir ortalamaya sahip olduklarını işaret etmektedir. Anlaşılmaktadır ki bu ortalama, istatistiksel yönden belirgin bir fark olarak açıklanmamaktadır. Bu noktada, deney grubunda verilen eğitimin peşrev türü eserin notalarını doğru çalma becerilerini önemli ölçüde artırmadığı görülmektedir.

\section{2 İkinci Alt Probleme İlişkin Bulgular}

$\mathrm{Bu}$ aşamada, öğrencilerin peşrev türündeki eserleri doğru ritimle çalabilme becerileri sınanmış ve uygulanan Mann - Whitney U Testi sonucunda istatistiksel yönden belirgin bir farka ulaşılıp ulaşılmadığı belirlenmiştir. Tablo 3. 3’e göre elde edilen sonuçlar aşağıda ki gibidir.

Tablo 3.3. Deney ve kontrol grubunun peşrev eserinde doğru ritimle çalabilme becerilerine yönelike ön test puanlarna ilişkin Mann - Whitney U Testi sonuçlar

\begin{tabular}{llccccc}
\hline Grup & $\mathbf{n}$ & S1ra Ortalamasi & Sira Toplami & U & Z & p \\
\hline Deney & 4 & 5 & 20 & 6.000 & -1.000 & .317 \\
Kontrol & 4 & 4 & 16 & & & \\
\hline Toplam & 8 & & & & & \\
\hline
\end{tabular}


Uludağ, A. K., \& Devecioğlu, F. (2020). Batı müziği keman icracıllğı tekniklerinin Türk müziği keman öğretimi alanında kullanılabilirlik düzeylerinin belirlenmesi. Journal of Human Sciences, 17(2), 432-457. doi:10.14687/ihs.v17i2.5788

Tablo 3. 3 incelendiği zaman her iki gurupta yer alan öğrencilerin peşrev türündeki eseri doğru ritimle çalabilme becerilerine ilişkin puanlarında istatistiksel olarak belirgin bir fark tespit edilmemiştir. (U=6,000; $\mathrm{p}>0.05)$. Sıra ortalamaları dikkate alındığ1 zaman deney grubu öğrencilerinin kontrol grubuna göre daha yüksek bir ortalamaya ulaştıkları anlaşılmaktadır. Bu durum, istatistiksel olarak belirgin bir fark olarak değerlendirilmemektedir.

Öğrencilerin, peşrevleri ne derece doğru bir ritimle çalabildiklerini belirlemek amaciyla Mann - Whitney U Testi uygulanmıştır ve istatistiksel olarak belirgin bir farkın var olup olmadığ1 tespit edilmiştir. Sonuçlar tablo 3. 4'de görüldüğü gibidir.

Tablo 3.4. Deney ve kontrol grubunun peşrev eserinde doğru ritimle çalabilme becerilerine yönelik son test puanlarna iliskin Mann - Whitney U Testi sonuclar

\begin{tabular}{llccccc}
\hline Grup & $\mathbf{n}$ & S1ra Ortalamas1 & S1ra Toplami & U & Z & p \\
\hline Deney & 4 & 5.25 & 21 & 5.000 & -.949 & .343 \\
Kontrol & 4 & 3.75 & 15 & & & \\
\hline Toplam & 8 & & & & & \\
\hline
\end{tabular}

Tablo 3. 4.`e göre kontrol ve deney grubu öğrencilerinin son test puanlarında istatistiksel olarak belirgin bir fark belirlenmemiştir ( $U=5,000 ; \mathrm{p}>0.05)$. Sira ortalamaları, deney grubu öğrencilerinin kontrol grubu öğrencilerine göre eserleri doğru ritimle çalabilme becerileri bakımından yüksek bir ortalamaya sahip olduklarını göstermektedir. Bu sonucun, istatistiksel olarak belirgin bir fark oluşturmadığı anlaşılmaktadır. Bu durum göstermektedir ki, deney grubu için hazırlanan deneysel işlem süreci, katılımcıların peşrev türü eserleri doğru ritimle çalabilme noktasında etkili olmuştur.

\section{3 Üçüncü Alt Probleme İlişkin Bulgular}

Öğrencilerin peşrev türündeki eseri seslendirirken sağ eldeki teknik davranışları yapabilme becerileri ölçülmüş ve sonuçlar Tablo 3. 5. ’te sunulmuştur.

Tablo 3.5. Deney ve kontrol grubunun pessrev eserinde săg eldeki teknik davramışlar yapabilme becerilerine yönelik ön test puanlarma ilişkin Mann - Whitney U Testi sonuclarn

\begin{tabular}{llccccc}
\hline Grup & $\mathbf{n}$ & S1ra Ortalamas1 & S1ra Toplami & U & Z & p \\
\hline Deney & 4 & 5.25 & 21 & 5.000 & -.949 & .343 \\
Kontrol & 4 & 3.75 & 15 & & & \\
\hline Toplam & 8 & & & & & \\
\hline
\end{tabular}

Tablo 3.5. incelendiği zaman kontrol ve deney grubu öğrencilerinin sağ eldeki teknik davranışları yapabilme becerilerine ilisskin puanlarında istatistiksel olarak belirgin bir fark tespit edilmemiştir. (U=5,000; $\mathrm{p}>0.05)$. Sıra ortalamaları incelendiği zaman deney grubu öğrencileri lehine yüksek bir ortalamaya ulaşılmıştır. Bu ortalamanın istatistiksel açıdan önemli bir farka yol açmadığı söylenebilir.

Bu sonuçlarla birlikte öğrencilerin sağ eldeki teknik davranışları yapabilme becerilerinin son test sonuçları belirlenmiştir. Sonuçlar tablo 3. 6.`da görüldüğü gibidir.

Tablo 3.6. Deney ve kontrol grubunun pessrev eserinde săg eldeki teknik davranışlar yapabilme becerilerine yönelike son test puanlarma ilişkin Mann - Whitney U Testi sonuclar

\begin{tabular}{llccccc}
\hline Grup & $\mathbf{n}$ & Sira Ortalamas1 & Sira Toplami & U & Z & p \\
\hline Deney & 4 & 6.5 & 26 & .000 & -2.530 & .011 \\
Kontrol & 4 & 2.5 & 10 & & & \\
\hline Toplam & 8 & & & & & \\
\hline
\end{tabular}


Uludağ, A. K., \& Devecioğlu, F. (2020). Batı müziği keman icracıllğı tekniklerinin Türk müziği keman öğretimi alanında kullanılabilirlik düzeylerinin belirlenmesi. Journal of Human Sciences, 17(2), 432-457. doi:10.14687/jhs.v17i2.5788

Tablo 3. 6. incelendiği zaman kontrol ve deney grubu öğrencilerinin peşrev türündeki eserleri seslendirirken sağ eldeki teknik davranışları yapabilme becerileri ortaya konmuştur. $\mathrm{Bu}$ noktada önemli bir sonuç göze çarpmakta ve öğrencilerin son test puanlarında istatistiksel olarak belirgin bir farkin olduğu görülmüş̧ür $(\mathrm{U}=, 000 ; \mathrm{p}<0.05)$. Elde edilen sonuç göstermektedir ki, deney grubunda verilen eğitimin öğrencilerin peşrev türündeki eserleri seslendirirken sağ eldeki teknik davranışları yapabilme becerilerini önemli ölçüde artırmıştır.

\subsection{Dördüncü Alt Probleme İlişkin Bulgular}

Çalışma grubu öğrencilerinin peşrev türündeki eserlerde sol eldeki teknik davranışları yapabilme becerileri sınanmıştır. Bu aşamada ki ön test sonuçlarında istatistiksel yönden belirgin bir farka ulaşılıp ulaşılmadığı belirlenmiş ve sonuçlar tablo 3. 7.`de gösterilmiştir.

Tablo 3.7. Deney ve kontrol grubunun peşrev eserinde sol eldeki teknik davramsslar yapabilme becerilerine yönelik ön test puanlarna ilişkin Mann - Whitney U Testi sonuclar

\begin{tabular}{lcccccc}
\hline Grup & $\mathbf{n}$ & S1ra Ortalamasi & Sira Toplami & U & Z & p \\
\hline Deney & 4 & 4.5 & 18 & 8.000 & .000 & 1.000 \\
Kontrol & 4 & 4.5 & 18 & & & \\
\hline Toplam & 8 & & & & & \\
\hline
\end{tabular}

Tablo 3. 7.`ye göre kontrol ve deney grubu öğrencilerinin peşrev türündeki eserde sol eldeki teknik davranışları yapabilme becerilerine ilişkin puanlarında istatistiksel olarak belirgin bir fark tespit edilmemiştir. (U=8,000; $\mathrm{p}>0.05)$. Araştırmanın bu sürecinde sıra ortalamaları açısından her iki grubun eşit puanlara sahip oldukları görülmüştür. Diğer bir ifadeyle öğrencilerin sol eldeki teknik davranışları yapabilme becerileri aynıdır.

$\mathrm{Bu}$ aşamada ise öğrencilerin peşrev içerikli eserleri sol eldeki teknik davranışları eşliğinde yapabilme becerileri ölçülmüştür. Elde edilen son test sonuçları tablo 3. 8. 'de gösterilmiştir.

Tablo 3.8. Deney ve kontrol grubunun pesrev eserinde sol eldeki teknik davranıslar yapabilme becerilerine yönelike son test puanlarna ilișkin Mann - Whitney U Testi sonuçlar

\begin{tabular}{llccccc}
\hline Grup & $\mathbf{n}$ & Sira Ortalamasi & Sira Toplami & U & Z & p \\
\hline Deney & 4 & 6.5 & 26 & .000 & -2.428 & .015 \\
Kontrol & 4 & 2.5 & 10 & & & \\
\hline Toplam & 8 & & & & & \\
\hline
\end{tabular}

Tablo 3.8. incelendiği zaman bir önceki aşamalardan farklı olarak öğrencilerin son test puanlarında istatistiksel olarak belirgin bir farka ulaşıldığ1 görülmüştür $(\mathrm{U}=, 000 ; \mathrm{p}<0.05)$. Bu fark araştırmanın amacını olumlu yönde etkileyen önemli bir faktördür. Bu sonuç şunu göstermektedir; deney grubunda konuya yönelik (bkz. tablo 3.8) hazırlanan deneysel işlem süreci, öğrencilerin keman çalma becerilerini önemli düzeyde artırmıștır.

\subsection{Beşinci Alt Probleme İlişkin Bulgular}

Öğrencilerin peşrev türündeki eserleri doğru tempo ile çalabilme becerilerinin ön test sonuçları tablo 3. 9. ¿da sunulmuştur.

Tablo 3.9. Deney ve kontrol grubunun peșrev eserinde doğru tempo ile çalabilme becerilerine yönelik ön test puanlarna iliskin Mann - Whitney U Testi sonuclarn

\begin{tabular}{llccccc}
\hline Grup & $\mathbf{n}$ & S1ra Ortalamas1 & Sira Toplami & U & Z & p \\
\hline Deney & 4 & 4.5 & 18 & \multirow{2}{*}{8.000} & .000 & \multirow{2}{*}{1.000} \\
Kontrol & 4 & 4.5 & 18 & & & \\
\hline Toplam & 8 & & & & & \\
\hline
\end{tabular}


Uludağ, A. K., \& Devecioğlu, F. (2020). Batı müziği keman icracıllğı tekniklerinin Türk müziği keman öğretimi alanında kullanılabilirlik düzeylerinin belirlenmesi. Journal of Human Sciences, 17(2), 432-457. doi:10.14687/ihs.v17i2.5788

Tablo 3. 9.`a göre kontrol ve deney grubu öğrencilerinin doğru tempo ile çalabilme noktasında belirgin bir fark tespit edilmemiştir $(\mathrm{U}=8,000 ; \mathrm{p}>0.05)$. Sıra ortalamaları ise her iki grubun eşit puana sahip olduklarını göstermektedir.

Gruplar arasında istatistiksel yönden belirgin bir farkın var olup olmadığı belirlenmiş ve sonuçlar tablo 3. 10. 'da gösterilmiştir.

Tablo 3.10. Deney ve kontrol grubunun peşrev eserinde doğru tempo ile çalabilme becerilerine yönelik son test puanlarna iliskin Mann - Whitney U Testi sonuclar

\begin{tabular}{lcccccc}
\hline Grup & $\mathbf{n}$ & S1ra Ortalamas1 & S1ra Toplami & U & Z & p \\
\hline Deney & 4 & 6.38 & 25.5 & .000 & -2.381 & .017 \\
Kontrol & 4 & 2.63 & 10.5 & & & \\
\hline Toplam & 8 & & & & & \\
\hline
\end{tabular}

Tablo 3. 10. incelendiği zaman her iki grupta yar alan öğrencilerin doğru tempo ile çalabilme becerilerine yönelik son test puanlarında istatistiksel açıdan önemli bir fark ortaya çıkmıştır ( $\mathrm{U}=, 000$; $\mathrm{p}<0.05)$. Bu fark, deney grubu için uygulanan deneysel işlem etaplarının oldukça etkili olduğunu işaret etmektedir.

\subsection{Altıncı Alt Probleme İlişkin Bulgular}

Bu aşamada, öğrencilerin müzikal ifade düzeyleriyle birlikte doğru bir tempoda çalabilme becerileri tespit edilerek ulaşılan sonuçlar tablo 3. 11.'e aktarılmıştır.

Tablo 3.11. Deney ve kontrol grubunun peşrev eserinde mürikal ifadeyle kabul edilebilir bir tempoda çalabilme becerilerine yönelik ön test puanlarna ilișkin Mann - Whitney U Testi sonuclar

\begin{tabular}{lcccccc}
\hline Grup & $\mathbf{n}$ & Sira Ortalamas1 & S1ra Toplami & U & Z & p \\
\hline Deney & 4 & 3.5 & 14 & 14.000 & -1.528 & .127 \\
Kontrol & 4 & 3.5 & 22 & & & \\
\hline Toplam & 8 & & & & & \\
\hline
\end{tabular}

Tablo 3. 11.'de görüldüğü üzere katılımcıların puanlarında istatistiksel olarak belirgin bir fark tespit edilmemiştir $(\mathrm{U}=4,000 ; \mathrm{p}>0.05)$. Benzer biçimde her iki grup arasında sıra ortalaması açısından yüksek bir sonuç görülse bile bu durumun istatistiksel yönden önemli bir fark oluşturmadığı anlaşılmaktadır

Tüm öğrencilerin son test sonuçlarında istatistiksel yönden ortaya bir fark çıkıp çıkmadığı belirlenmiş ve bulgular tablo 3. 12.'de gösterilmiştir.

Tablo 3.12. Deney ve kontrol grubunun peşrev eserinde müzikal ifadeyle kabul edilebilir bir tempoda çalabilme becerilerine yönelik son test puanlarna iliskin Mann - Whitney U Testi sonuclar

\begin{tabular}{lcccccc}
\hline Grup & n & Sira Ortalamas1 & Sira Toplami & U & Z & p \\
\hline Deney & 4 & 6.5 & 26 & .000 & -2.494 & .013 \\
Kontrol & 4 & 2.5 & 10 & & & \\
\hline Toplam & 8 & & & & & \\
\hline
\end{tabular}

Deneysel işlem sürecine yönelik uygulanan testlerin en son aşamasında tablo 3. 12.`den anlaşlacağı üzere öğrencilerin son test puanlarında istatistiksel olarak belirgin bir fark tespit edilmiştir ( $\mathrm{U}=, 000 ; \mathrm{p}>0.05)$. Ulaşılan bu bulgu, araştırmanın amacını ve önemini olumlu yönde etkilemiştir. Yapılan uygulamalar göstermiştir ki; deney grubu için hazırlanan çalışmalar, öğrencilerin peşrev türündeki eseri müzikal ifadeyle kabul edilebilir bir tempoda çalabilme becerilerini önemli ölçüde artırmıştır. 
Uludağ, A. K., \& Devecioğlu, F. (2020). Batı müziği keman icracıllğı tekniklerinin Türk müziği keman öğretimi alanında kullanılabilirlik düzeylerinin belirlenmesi. Journal of Human Sciences, 17(2), 432-457. doi:10.14687/jhs.v17i2.5788

\section{SONUÇ VE ÖNERİLER}

Elde edilen sonuçlar bir bütün olarak değerlendirdiğinde, son test aşamasının ardından deney grubu öğrencilerinin kontrol grubu öğrencilerine göre daha başarılı olmaları ve deneysel işlem sürecinin herhangi bir aksaklığa uğratılmadan gerçekleştirilmesi, araştırmanın amacı ile anlamlı derecede örtüştüğünü göstermektedir. Batı müziği keman eğitimi bünyesinde kullanılan sağ ve sol el tekniklerinin Türk müziği keman eğitimine aktarılmasıyla yürütülen deneysel işlem süreci sonucunda, etkili bir süreç gerçekleştirilmiştir. Buna ek olarak öğrencilerin motivasyonlarında ve derse karşı ilgilerinde gözle görülür bir artış olduğu saptanmıştır. Öğrencilerin son test aşaması sonucunda elde ettikleri yüksek puanlar, bu artışı destekleyen en önemli argümanlardır.

Araştırmanın uygulama sürecini kapsayan çalışmalar içerisinde çeşitli makam ve usûllerin kullanıldığ1 görülmektedir. Bu materyaller, keman eğitiminde bulunan sağ ve sol el teknikleri önemli derecede bütünlük sağlamıştır. Bu çalışma sonucunda, Türk müziğinde alışlagelmiş ve sistematik bir yapıya oturtulamamış olan icracılık boyutlarına karşılık önemli bir alternatif çalg1 eğitimi anlayışı kazandırıldığı düşünülmektedir. Bu alışıla gelmişlik, sağ ve sol el tekniklerin kullanımı, icracıların bireysel farkllık gibi özelliklerdir. İcracıların farklı icralarından dolayı, Türk müziği süsleme teknikleri zenginlik göstermektedir. Gürel'e (2011) göre bu olumsuzluklar, Türk müziği keman eğitiminde yıllardır süregelen akademisyen eksikliğinin yanı sıra metot yetersizliğinden de kaynaklanarak Türk müziği keman eğitiminde bir sistemsizliği ortaya çıkarmıştır. Araştırma içerisinde sağ ve sol el tekniklerin kullanılması ve bunun olabildiğince bir sistem içerisinde tasarlanması, çalgı eğitimi alanında konuya ilisskin varsayılan eksikliklere yönelik önemli bir adım olarak değerlendirilebilir. Karşılaşılması öngörülen birtakım zorlukların aşılmasında basitten karmaşığa doğru bir işlem sürecinin yürütülmesi esas alınmıştır.

Bu çalş̧ma sonucuna bağlı kalarak bazı öneriler getirilmiştir. İlk olarak Hatipoğlu’nun (2013) belirttiği üzere; keman sazının, mesleki müzik eğitimi kapsamında yürütülen Türk müziği keman eğitim - öğretim süreci içerisinde programlı bir biçimde yapılamaması en temel sorundur. Bu sorun karşısında; planlı, programlı ve uzman görüşleri doğrultusunda hazırlanacak bir Türk müziği keman eğitimi sistemi geliştirilebilir ve yaygınlaştırılabilir. Bu tarz çalışmaların, yaylı çalgılar ailesinin diğer üyelerine de uyarlanması düşünülebilir. Bu araştırma kapsamında kullanılan deneysel işlem sürecinin etkiler, farklı çalışma gruplarına aktırılabilir ve elde edilen farklı sonuçlar üzerinden daha geniş bir bakış açısı geliştirilebilir. Bununla birlikte Türk müziği içerikli keman eğitimi materyallerinin sayısı artırılabilir. Tüm bunların, teknik ve icracılık boyutunda verimliliğin arttırılması bakımından önemli olduğu unutulmamalıdır. Geleneksel müziklerin kendine özgü makamsal özelliklerinin keman eğitimi için değerli bir materyal olma özelliğinden yola çıkarak eğitim sürecinde faydalanabilmek amacıyla makamsal etüt ve alıştırmalar daha yoğun hale getirilebilir. Bu noktada Parasız (2009) mevcut olan makamsal keman etüt ve alıştırmaların nitelik ve nicelik bakımından yeterli olmadığına dikkat çekmektedir. Kurtaslan (2009) ulusallı ve evrenselliğin bir bütün olarak alg1landığı çağımızda, ulusal içerikli eğitsel amaçlı eser ve metotların sayı bakımından artırılmasını, keman eğitimcilerinin de özendirilmesi gerektiğini önermektedir.

\section{KAYNAKÇA}

Alkaç, G., \& Kaya, F. (2017). Yükseköğretim kurumlarındaki Türk müziği çalg1 eğitimine kanun ve klasik kemençe örneklemi ile genel bir bakış. NWSAFA, 12(1), s. 17 - 29.

Büyüköztürk, Ş. (2010). Sosyal bilimler için veri analiẓi el kitabı (11. Baskı.). Ankara: Pegem Akademi Yayıncilik.

Büyüköztürk, Ş. (2014). Deneysel desenler (4. Bask1.). Ankara: Pegem Akademi Yayıncıllk.

Demirci, B. (2013). Viyolonsel eğitiminde geleneksel Türk müziğine yönelik bir çalısma modeli. Hacettepe Üniversitesi Eğitim Fakültesi Dergisi., 28(1), s. 117 - 129.

Devecioğlu, F. (2017). Batı müriğ keman icractlğg tekniklerinin Türk müriğ keman ögretimi alamnda kullanlabilirlike düzeylerinin belirlenmesi. Yayımlanmamış yüksek lisans tezi. Atatürk Üniversitesi Eğitim Bilimleri Enstitüsü, Erzurum. 
Uludağ, A. K., \& Devecioğlu, F. (2020). Batı müziği keman icracıllğı tekniklerinin Türk müziği keman öğretimi alanında kullanılabilirlik düzeylerinin belirlenmesi. Journal of Human Sciences, 17(2), 432-457. doi:10.14687/jhs.v17i2.5788

Gürel, M. (2011). Keman eğitiminde kullanulan süsleme tekniklerinin Türk mürĭgi keman icrasindaki uygulama biçimi ve buna yönelik alş̧trrmalarn olușturulması. Yayımlanmamış yüksek lisans tezi. Gazi Üniversitesi Eğitim Bilimleri Enstitüsü, Ankara.

Hatipoğlu, V. (2013). Rast makamındaki kâr - ı nâtık eserlerinden oluşturulan seyr - i nâtık örneğinin keman ögrretiminde kullanulabilirliğinin değerlendirilmesi. Rast makamındaki kâr - 1 nâtık eserlerinden oluşturulan seyr $\quad$ i nâtık örneğinin keman öğretiminde kullanılYayımlanmamış doktora tezi. Gazi Üniversitesi Eğitim Bilimleri Enstitüsü, Ankara.

Hatipoğlu, V. (2017). Türk müziği keman akrodu. İdil Sanat ve Dil Dergisi., 6(29), s. 289 - 309.

Kurtaslan, Z. (2009). Türk keman okulunun oluşum süreci ve temsilcileri. Türkiyat Araştırmalar Dergisi., 1(26), s. 409-429.

Kurtaslan, Z. (2009). Müzik öğretmeni yetiştiren kurumlarda ulusal keman eğitimi materyallerinin yeri ve önemi. 8. Ulusal Mürile Ë̆itimi Semposyumu.

Özkan, İ. H. (1998). Türk mûsıkîsi nazariyatı ve usûlleri kudüm velveleri. (5. Bask1.). Ankara: Ötüken Neşriyat.

Parasız, G. (2009). Keman öğretiminde kullanılmakta olan çağdaş Türk müriği eserlerinin seslendirilmesine yönelik olarak oluşturulan hą̧rlayıc alistormalarm isgörüsellik ve etkililik yönünden incelenmesi. Yayımlanmamış doktora tezi. Gazi Üniversitesi Eğitim Bilimler Enstitüsü, Ankara.

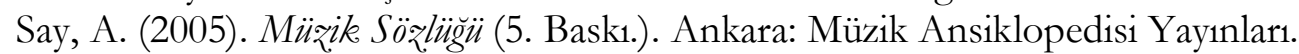

Tamay, S. (2015). Pozisyonlu çalış tekniği ile bağlama öğretiminde sarkma tekniğinin izahı. I. Uluslararası Mürite ve Dans Kongresi., s. 342 - 354.

Tamay, S., \& Matyakubov, B. (2019). Timur ve Bâyazid destanı. (1. Baskı.). Ankara: Gece Akademi Yayinları.

\section{Extended English Summary}

\section{Purpose}

The violin instrument is widely used in many types of music as a result of being fretless, performing with bow, and the characteristics of the instrument and the violin family (viola, cello and contrabass), such as the width of the sound range and the richness of performing techniques. What distinguishes Turkish music from Western music is the sound system. While tampere system is used in Western music, Turkish music uses 24 coma sound system. Apart from the sound, procedural, genre and form of Turkish music, an important feature is the tuning system. In Western music, the la note with a frequency of 440 hertz (A4) is accepted as the re (neva) note in Turkish music. This tuning system is called bolahenk. This study was carried out in abundant tuning system. As a result of the fact that Western music technical performances used in the violin instrument are not used much in Turkish music, it may reveal some deficiencies in the vocalizations of the existing works in Turkish music. This study primarily focuses on the teaching of Turkish Turkish violin instrument. This study was carried out with the aim of transforming Turkish music violin techniques into a more systematic structure in line with Western music violin performance techniques. Another important aim of this study is to determine the techniques used in violin teaching in the works of Turkish music genres, to identify the difficulties faced by the students in the works of Turkish music genres, and to examine the studies in the framework of the education system created for the works of Turkish Music in terms of visibility and effectiveness.

\section{Method}

Pre - test post - test control group model was used in the study. The research is an experimental study. An important problem in experimental studies is the selection of subjects. This problem is more important in pre - post - test control group designs. Because the differences of the scores of the dependent and experimental groups after the experiment may be due to the differences before the experiment (Büyüköztürk, 2014, p. 22). In the study, an equivalence test was applied at the initial stage to form the control and experimental groups. Önemli An important 
Uludağ, A. K., \& Devecioğlu, F. (2020). Batı müziği keman icracıllğı tekniklerinin Türk müziği keman öğretimi alanında kullanılabilirlik düzeylerinin belirlenmesi. Journal of Human Sciences, 17(2), 432-457. doi:10.14687/jhs.v17i2.5788

problem in experimental studies is the selection of subjects. This problem is more important in pre - post - test control group designs. Because the differences of the scores of the dependent and experimental groups after the experiment may be due to the differences before the experiment (Büyüköztürk, 2014, p. 22). In the equivalence test, asız Performance Evaluation Scale for Musical and Technical Skills was used in the Ph. D. This scale was prepared as a five-point likert. In order to determine the validity and reliability of the questions in this scale, Cronbach`s Alpha test statistic was used and its reliability was proved. "SPSS 20 " package program was used for data analysis. This study consisted of students $(n=8)$ who studied violin at the Department of Traditional Turkish Music of Kafkas University State Conservatory in fall and spring of 2015 - 2016. Non-parametric tests were used in the analyzes since there were four individuals in the control and experimental groups. Non-parametric tests should be used in cases where the sample size is less than 15 (Büyüköztürk, 2010, p. 8). Accordingly, - Mann-Whitney U Test was used to determine whether there was a significant difference between the pre-test and post-test results of the control and experimental group students. Mann - Whitney U Test is used to test whether the scores obtained from two unrelated samples differ significantly from each other (Büyüköztürk, 2010, p.155). It was accepted as 0.05 significance level in the analysis of the data.

\section{Results}

Mann - Whitney U Test was applied to determine whether there is a statistically significant difference in the pre - test and post - test results of the "Rast Peşrev" work performed by the right and left hand techniques of the experimental and control group students.

No statistically significant difference was found between the two groups in the last test of the first sub-problem of the study. ( $U=6,000 ; \mathrm{p}>0.05)$. However, when the average of the rankings are taken into consideration, it shows that the experimental group students are more successful than the control group students. In the posttest results of the 2nd sub-problem, no significant difference was determined between the two groups as in the 1st sub-problem results. (U=5,000; $\mathrm{p}>0.05)$. According to this result, when the rank averages are taken into consideration, it is seen that the experimental group students have a higher average than the control group students. When the post-test results of the 3rd sub-problem were examined, a statistically significant difference was found by the experimental group. ( $\mathrm{U}=, 000 ; \mathrm{p}>0.05)$. In the last test of the 4 th sub-problem, a statistically significant difference was detected by the experimental group. (U=,000; $>>0.05$ ). In the posttest results of the 5th sub-problem of the research, a statistically significant difference was detected by the experimental group. ( $\mathrm{U}=, 000 ; \mathrm{p}>0.05)$. When the posttest results of the 6th subproblem were examined, a statistically significant difference was found in the experimental group. $(\mathrm{U}=, 000 ; \mathrm{p}>0.05)$. Especially after the last test results, the experimental group had more successful scores than the control group. This shows that the experimental process (teaching system) applied in accordance with this result is positively effective. Again, based on these results, the use of right and left hand techniques in violin instruments in Turkish music works revealed musical expressions.

\section{Discussion}

As a result of the use of various makams and methods in the teaching system of the research, the techniques that can highlight the right and left hand techniques in the violin instrument. The traditional violin instrument is performed in Turkish music. This customary features include the use of right and left hand techniques, individual differences of performers. Due to the different performances of the performers, Turkish music decoration techniques are rich. However, this richness leads to a lack of system in the Turkish music violin education due to the lack of academicians in Turkish music violin education and the lack of methods (Gürel, 2011, p. 7). The use of right and left hand techniques applied in this study and performing this in a system may cause some problems at the beginning. It can be said that some of the difficulties to be faced will be solved by teaching technique from simple to complex applied in the research and bring positive 

kullanılabilirlik düzeylerinin belirlenmesi. Journal of Human Sciences, 17(2), 432-457. doi:10.14687/jhs.v17i2.5788

results. Some suggestions were made depending on the results of this study. It is suggested that the use of right and left hand techniques in violin instrument performances of Turkish music works should be prepared in a teaching system. It is recommended that this content be prepared according to "Linear Programming Approach (Tyleer + Bloom) in simple to complex, from unknown to unknown, in concrete to abstract order. An the most important problem is the lack of programmatic process of Turkish music violin education conducted within the scope of professional music education of the violin instrument developed especially at this level technically. (Hatipoğlu, 2013, p. 1). In this study, it was thought that it would be beneficial to adapt the strings to other members of the family of instruments and to extend the sample to other Turkish music genres.

\section{Conclusion}

When the results obtained are evaluated as a whole, the fact that the experimental group students are more successful than the control group students after the last test stage and the realization of the teaching system without any disruption shows that it overlaps significantly with the aim of the research. As a result of the experimental process carried out with the use of right and left hand techniques in Turkish music works, it is seen that there are no problems in the vocalization of the works in accordance with the curricula of the Turkish music department. There is also a significant increase in students' motivation and interest towards the course. The high scores of the students at the end of the last test stage are the most important arguments supporting this increase. 